\title{
C-LLAMA v1.0: a traceable model for food, agriculture and land-use
}

\author{
Thomas S. Ball ${ }^{1}$, Naomi E. Vaughan ${ }^{1,2}$, Thomas W. Powell ${ }^{3}$, Andrew Lovett ${ }^{1} \&$ Timothy M. Lenton $^{3}$.
}

${ }^{1}$ School of Environmental Sciences, University of East Anglia, Norwich, NR4 7TJ, UK

${ }^{2}$ Tyndall Centre for Climate Change Research, University of East Anglia, Norwich, NR4 7TJ, UK

$5{ }^{3}$ Global Systems Institute, University of Exeter, Exeter, EX4 4PY, UK

Correspondence to: t.ball@uea.ac.uk

\begin{abstract}
We present C-LLAMA 1.0 (Country-level Land Availability Model for Agriculture), a statistical-empirical model of the global food and agriculture system. Based on the FALAFEL (Flux Assessment of Linked Agricultural Food production,

10 Energy potentials \& Land-use change) model, C-LLAMA aims to address the need for an open and transparent approach to modelling the sensitivity of future agricultural land-use to drivers such as diet, crop yields and food-system efficiency. CLLAMA uses publicly available FAOSTAT data to make linear projections of diet, food system and agricultural efficiencies, and land-use at a national level, aiming to capture aspects of food systems in both developing and developed nations. In this paper we describe the structure and processes within the model and perform sensitivity analyses of key components.
\end{abstract}

\section{Introduction}

Land-use plays a critical role in achieving Paris Agreement temperature goals. Favoured climate change mitigation strategies such as biomass energy with carbon capture and storage (BECCS) and afforested rely heavily on widespread land-use change to achieve the necessary scales to be effective. However, a range of interlinked factors may jeopardise the sustainable deployment of these mitigation strategies; these include carbon leakage, ecosystem services and biodiversity, and the need for land to support human livelihood and food supply (Arneth et al., 2019). With growing global populations and wealth there are also increasing demands for food quantity and diversity, increasing pressure on the agricultural system to meet the demand (Allen et al., 2018; Alexander et al., 2016).

Integrated assessment models (IAMs) make comprehensive projections of future scenarios by coupling economics and landuse with simple carbon cycle and climate models. These models are driven by macro-economics, using a combination of dynamic and static input factors to project future scenarios and are the basis of the Paris Agreement warming targets (United Nations, 2015). Most IAMs deal with land-use, although there are some exceptions. Whilst IAMs are well suited to broad scale modelling of future scenarios, especially with policy-making in mind, they can be somewhat opaque in nature. Their outputs can be difficult to interpret in such a way that it becomes clear how different drivers affect land availability and suitability (Havlík et al., 2014; Popp et al., 2014; Calvin et al., 2013; Fujimori et al., 2012; Vuuren et al., 2011).

30 The biophysical aspects of land-use are typically assessed using dynamic global vegetation models (DGVMs), which examine soil and atmospheric carbon, hydrology, and vegetation interactions. Examples of these models are the Joint UK Land- 
Environment Simulator (JULES) (Best et al., 2011) and the Lund-Potsdam-Jena managed Land (LPJmL) model (Rolinski et al., 2018). The outputs of these models can be linked with IAM models to produce estimates for ecological parameters.

FALAFEL (Flux Assessment of Linked Agricultural Food production, Energy potentials \& Land-use change) is a global-level model, using linear projections of global food supply and agricultural efficiencies and yields to produce trajectories for landuse, carbon capture and energy to 2050 (Powell, 2015; Powell \& Lenton, 2012). C-LLAMA (Country-Level Land Availability Model for Agriculture) is based on the same principles and processes as FALAFEL but disaggregated to the country level. It produces a land-use trajectory to 2050 for each food commodity and commodity group within a country. C-LLAMA is built in Python (Van Rossum and Drake Jr, 1995), unlike FALAFEL which is built in Microsoft Excel. The advantages of this are

40 twofold; manipulation of large data is computationally faster, and a code-based model facilitates greater flexibility in model development and expansion.

C-LLAMA is situated at the opposite end of the modelling spectrum to IAMs; taking a bottom-up approach to modelling future land availability; assuming that the global population is fed and remains so, then projecting food demand and production forward from that assumption. In a similar approach to that of FALAFEL, Bijl et al. (2017) consider the relationships between

45 income and dietary patterns to model long-term food demand, but halt at the crop demand stage. C-LLAMA has no economic considerations but models the full range of the food-system from the consumer to the production of crops and animal products. Where FALAFEL and Bijl et al. model the food-system at a global and regional level, C-LLAMA operates at a national level.

\section{Model overview}

C-LLAMA is a statistical-empirical model that uses data from FAOSTAT (Food and Agriculture Organization of the United

50 Nations, 1997) as the primary input, which can be found at www.fao.org/faostat/en/\#data. These datasets contain food supply and production data from 1961 to 2013 at a country level. C-LLAMA models the same timespan as FALAFEL: from 2013 to 2050. Many of the processes in the model are the same as those in the FALAFEL but operate at a country level as opposed to being globally aggregated. An overview of the structure of C-LLAMA and a brief description of the model sections are given in Fig. 1 and Table 1 respectively. 


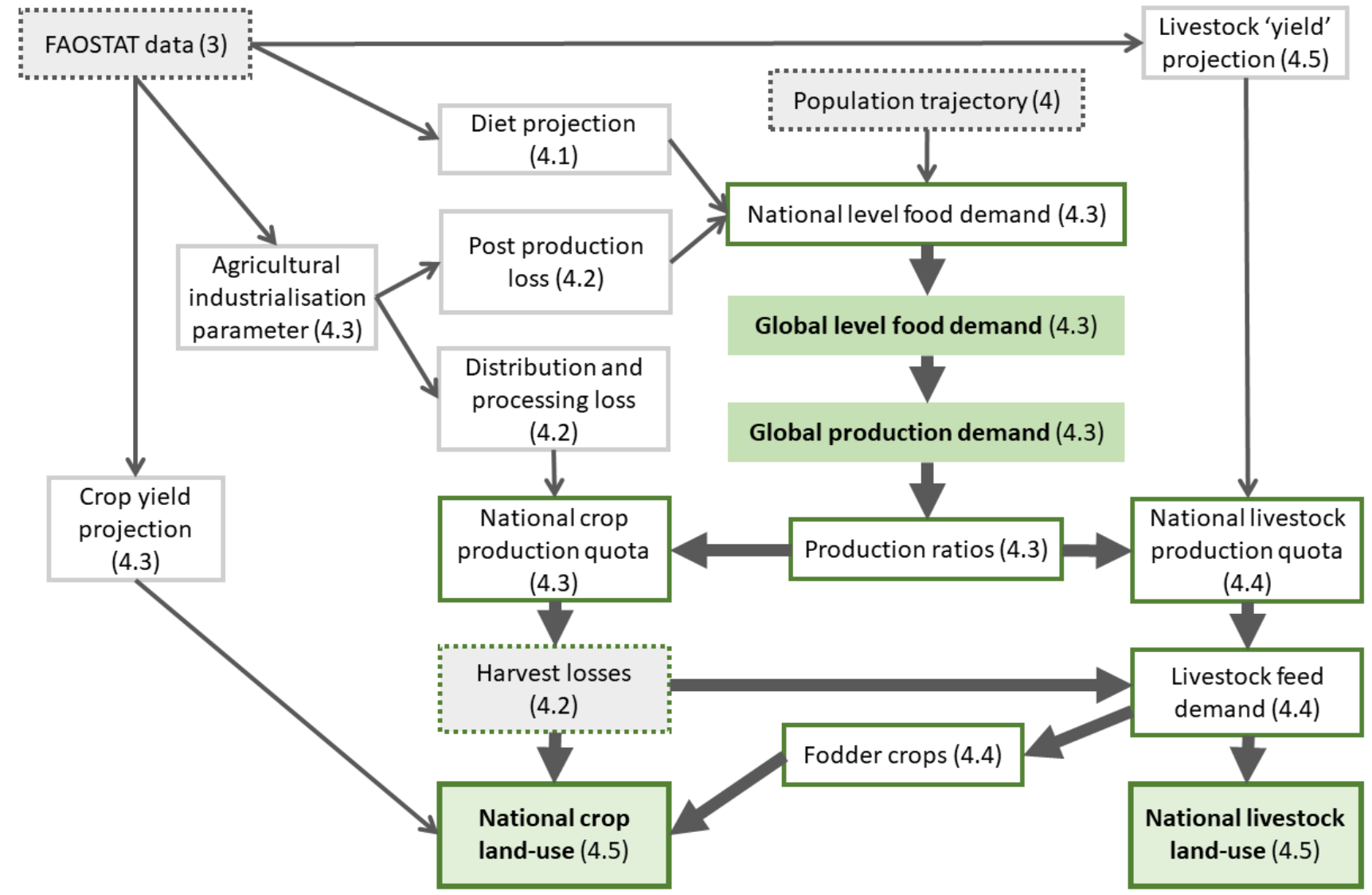

Figure 1: Overview of C-LLAMA Model structure and flow, with relevant section numbers within the paper indicated in parentheses. Boxes with a dotted border are external datasets while a solid border represents values calculated in CLLAMA. Thick arrows represent a flow of mass or energy, thin arrows represent the contributing trajectories or factors. Boxes outlined in green are core processes. Boxes shaded in green are globally summed quantities. National crop land-use and livestock land-use are shaded and outlined in green, to highlight them as the primary output of the model. Not all model processes and connections are depicted, this diagram gives a general overview of C-LLAMA.

\begin{tabular}{|l|l|l|}
\hline Model Section & Description of processes within the section & Relevant modules \\
\hline Diet and food supply & $\begin{array}{l}\text { Projections of the contribution of each food } \\
\text { commodity toward the national diet. Projection } \\
\text { of national calorie supply per capita. }\end{array}$ & $\begin{array}{l}\text { diet_makeup } \\
\text { Calculation of a global demand for each food } \\
\text { commodity. }\end{array}$ \\
\hline
\end{tabular}


industrialisation_metric

industrialisation_metric_calculations

efficiency used at various stages of the model. An agricultural industrialisation metric is developed to inform these values.

Losses are used to calculate total production requirement for each food commodity, a portion of which is then allocated to each country. Crop yields are projected for each food and fodder crop in the model.

food_waste_gen

harvest_residues

crop_yield_and_production_hist

crop_yield_and_production_params

crop_yield_projects

crop_and_livestock_production crop_production_ratios

\begin{tabular}{|l|l|l|}
\hline Livestock & $\begin{array}{l}\text { The global production requirement for livestock } \\
\text { is calculated and allocated to each country. } \\
\text { Livestock consume a mix of feed and foraged } \\
\text { food, the proportion coming from each varies by } \\
\text { livestock type and country. }\end{array}$ & $\begin{array}{l}\text { livestock_feed_demand } \\
\text { fodder_crops }\end{array}$ \\
\hline Land use & $\begin{array}{l}\text { Production requirement energy is converted to } \\
\text { mass and combined with yield to produce a land } \\
\text { area requirement for both food and fodder crops. } \\
\text { An 'effective livestock yield' is developed and } \\
\text { used to calculate pasture land requirements. }\end{array}$ & pasture_land_calculations \\
\hline
\end{tabular}

Table 1. Five main sections within C-LLAMA, each comprised of a handful of model-process modules. There are sixteen model-process modules in total.

Table 1 lists all the modules responsible for model processes in C-LLAMA, grouped into model sections. There is some overlap

65 between the model-processes; the sections and model-process modules listed here are not necessarily in the order that they appear in C-LLAMA, some sections are re-visited at later stages of the model. The first section of the model produces a food supply at a national level, disaggregated into calories and commodities.

The model operates across five continents: Africa, the Americas, Asia, Europe and Oceania, C-LLAMA then splits these into further subcontinental regions (for example, the Americas are split into N. America, S. America, Central America and the

70 Caribbean), most of which contain several countries or states. The model is structured into the following four spatial aggregations: global, continent, region, and country, aligning with the United Nations Statistics Division (UNSD), with each model process operating at one of these levels. 
https://doi.org/10.5194/gmd-2021-169

Preprint. Discussion started: 13 July 2021

(c) Author(s) 2021. CC BY 4.0 License.

(c) (i)

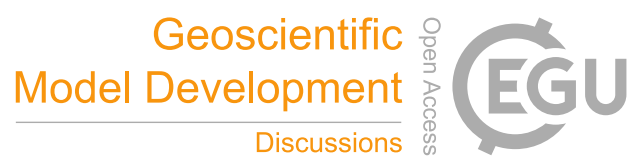

Global food production and demand is dominated by a small handful of countries, illustrated by Fig. 2. For example: Brazil, the USA and Argentina together accounted for $52 \%$ of global food production by mass in 2017. Of the 162 countries in the

75 FAOSTAT data, the 100 most food-productive countries account for $99.7 \%$ of the total production mass. The remaining 62 countries account for only $0.3 \%$ of the total food production. Countries whose food production mass in 2017 equates to less than $0.01 \%$ of the 2017 global total and whose agricultural land-area is less than 34,000 hectares are discounted from the model processes, illustrated in Fig. 3. This is done in C-LLAMA for two reasons. The first is to reduce unnecessary model run-time and development complexity. The second reason is that many of these countries have reduced data quality and 80 availability due to their size. Often the data is discontinuous, most commonly due to changes in reporting or assessment. This can lead to unrealistic behaviour when making projections of the data as C-LLAMA does.

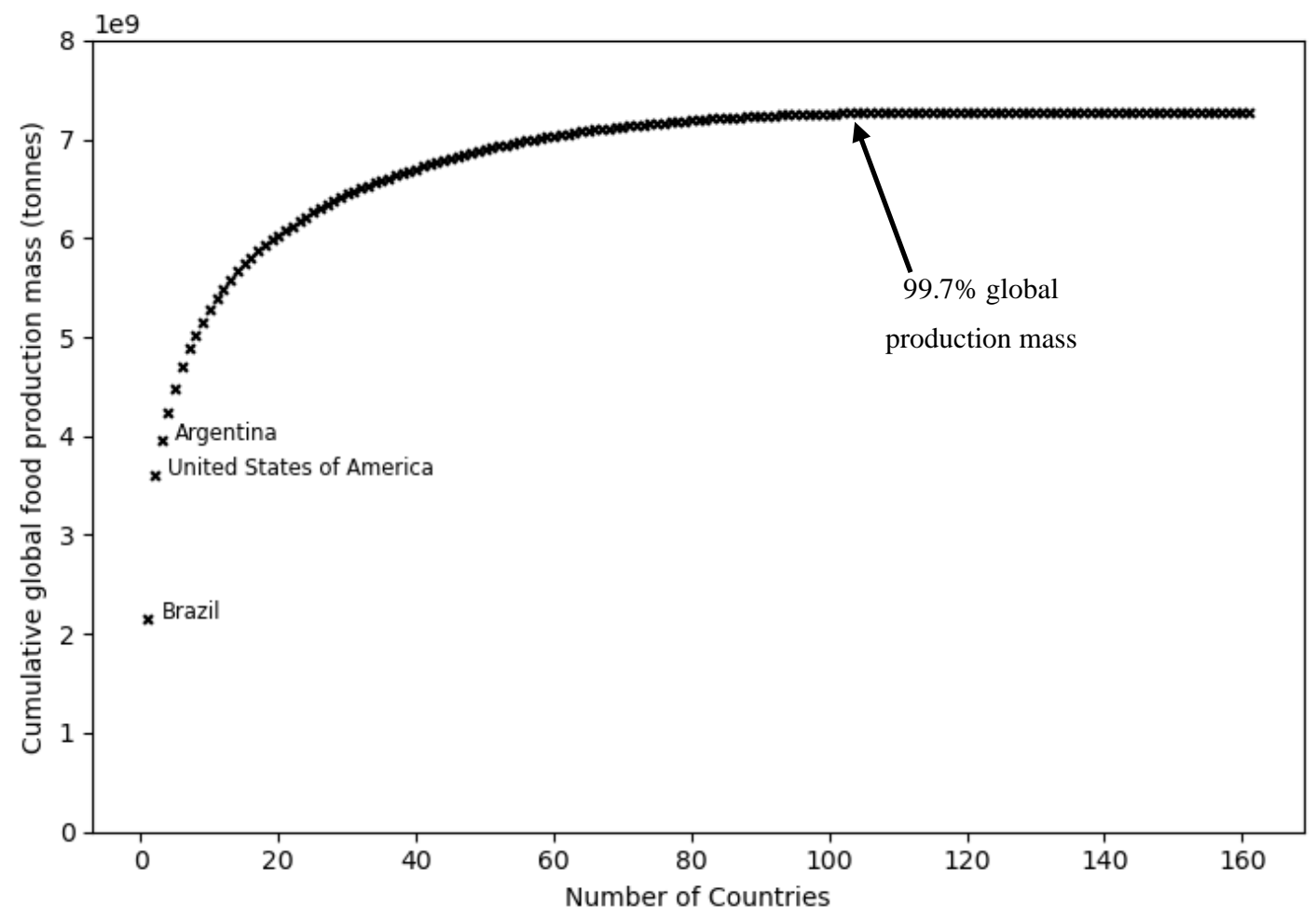

Figure 2. Cumulative food production mass for the year 2017 of all current countries in the FAOSTAT database, dissolved states are not included. 


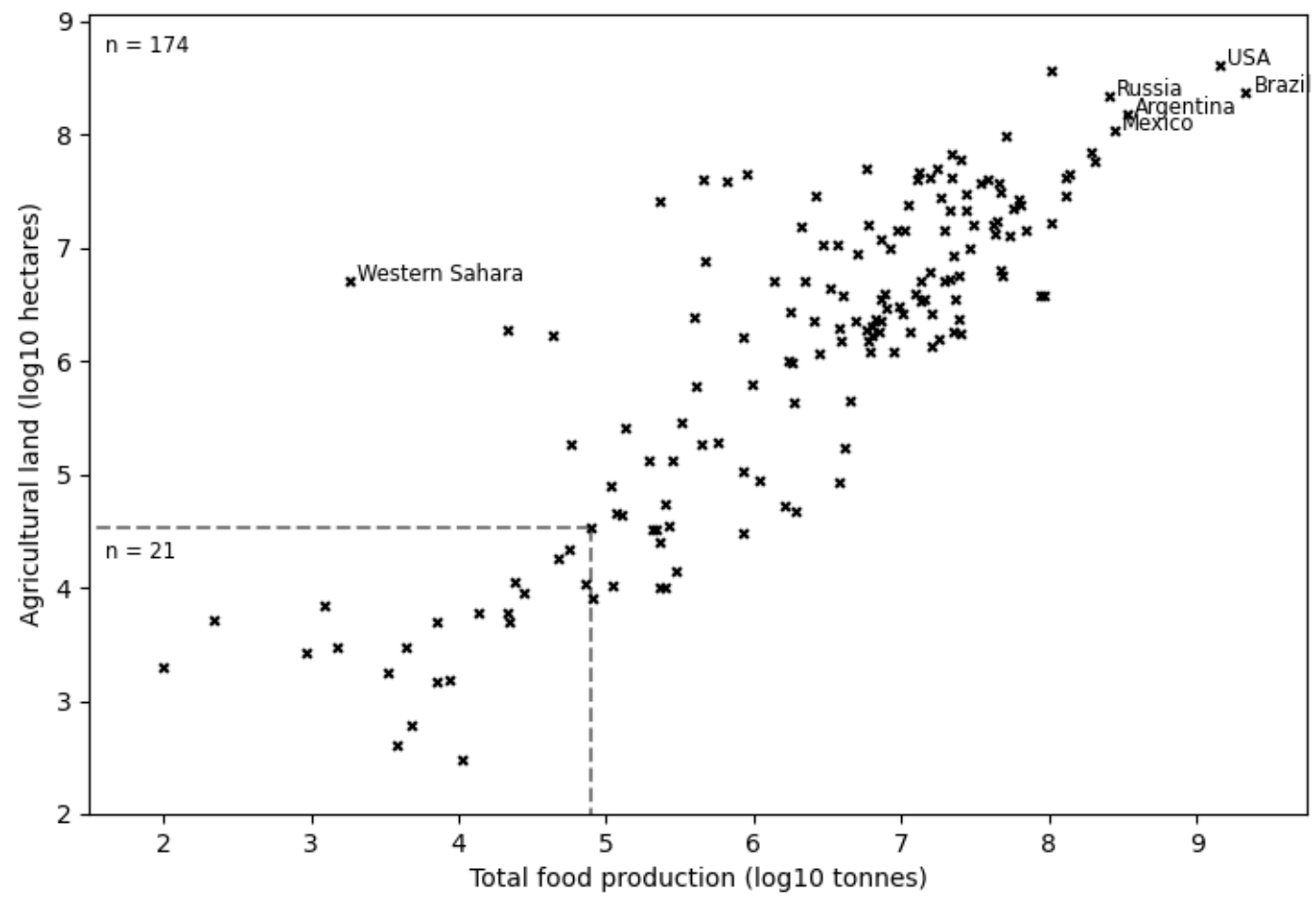

Figure 3. Log of agricultural land area against total food production mass for the year 2017 for all countries in the FAOSTAT database, dissolved states are not included. Countries contained in the small dotted-line box are not included in model processes $(n=21)$, while the remaining countries are included $(n=174)$.

There are a small number of countries not included in the model processes because no food balance data for them is available from the FAOSTAT database. The reason for this in most cases is a recent history of political instability or conflict, which suggests that motivating land-based climate mitigation action in these regions may be difficult (World Bank, 2020). Notable for their large land areas, Libya, Sudan, Somalia, and the Democratic Republic of the Congo in Africa (DRC), and Papua New Guinea in Oceania are not included in the dataset, a total land area of 500 Mha. Despite their large land areas, Libya, the DRC, and Papua New Guinea have a small amount of agricultural land for their size at less than $10 \%$, and as low as $2 \%$ in the case of Papua New Guinea. Sudan has 40\% agricultural land coverage and Somalia has $70 \%$.

\section{Model components}

\subsubsection{Population}

C-LLAMA uses population trajectories from the shared socio-economic pathways (SSP) database, available as 5-yearly population values for each country. SSP2 is a middle of the road scenario with corresponding population projection based on medium values for fertility, mortality, education and migration (KC and Lutz, 2017). The SSP2 population projection is used 
as a default but any population projection data can be applied. The population data is interpolated linearly to produce a yearly population trajectory to 2050 .

\subsection{Food supply}

We define food supply for a given country to be the mean number of kilocalories used per capita per day in a given year. This includes any post-production food waste; some food reaches consumers but is never eaten, either commercially or as domestic waste. The proportion of food wasted in this way is as high as 30\% in most developed countries (Alexander et al., 2017).

FAOSTAT food balance sheets contain food supply data disaggregated into different food commodities (Food and Agriculture Organization of the United Nations, 1997). C-LLAMA uses this data to produce a projected food demand for each country. First, the generous goal of an ample westernised diet for everyone is set: an assumed $2500 \mathrm{kcal}$ food intake per day per capita,

110 with an additional 28\% wasted, giving an idealised food supply of 3200 kcal (Kearney, 2010; Alexander et al., 2017; Parfitt et al., 2010). A linear projection is made for each country from their current food supply to the idealised food supply in a given year, using the following equation:

$F(n)=F_{0}+\frac{n-n_{0}}{n_{\text {target }}-n_{0}}\left(F_{\text {target }}-F_{0}\right)$

where $F_{n}$ is the food supply in year $n, F_{\text {target }}$ is the idealised food supply per capita, $F_{0}$ is the mean of the most recent five years of historical food supply data. $n_{0}$ and $n_{\text {target }}$ are the starting year of the projection and the chosen year to reach the idealised food supply, set at 2100 by default. Values of $n_{\text {target }}$ beyond 2050 mean that the idealised food supply is not reached during the modelled time period.

Secondly, a linear regression is used to make a projection for the calorie supply from each of the food groups animal products, vegetal products, and aquatic products. Regression lines with a p-value greater than 0.05 are discounted (this threshold value can be changed), instead fixing the projection at the mean value of the most recent five years of data. These projections are then converted into fractions. The proportion of food supply $(P)$ made up by group $i$ in year $n$, is given by

$P_{i}(n)=\frac{a_{i} n+b_{i}}{\sum_{g \in G}\left(a_{g} n+b_{g}\right)}$,

where $a$ and $b$ are the gradient and intercept of the regression line for that group and $G$ is the set of groups: animal, vegetal and aquatic products.

125 Third, the same process is applied to individual food commodities within the three food groups. Key food commodities are represented individually, for example wheat, maize and rice in the vegetal product group, and bovine meat and poultry meat in the animal product group. Other commodities are represented in groups, for example 'cereals - other' contains all cereals that are not singled out as key commodities, while the 'luxuries' group contains all tea, coffee, and alcohol. Aquatic products are not the focus of the model as they have minimal to no land requirements during their production; thus they are placed in a

130 single group. Hence, in C-LLAMA, aquatic products simply offset some of the calorific demand from the other food groups. Where possible, C-LLAMA uses vegetal product groups defined in FAOSTAT data. A full list of food commodities and 
groupings can be found in Appendix A. The commodities within a group are then converted into ratios, so the proportional calorific contribution of commodity $j$ to its umbrella food group $i$ in year $n$ is

$P_{j}(n)=\frac{a_{j} n+b_{j}}{\sum_{c \in C}\left(a_{c} n+b_{c}\right)}$

where $a$ and $b$ are the gradient and intercept respectively of the regression line for that commodity and $C$ is the set of commodities within the group, for example if $j$ is wheat then $C$ would be all vegetal products. The structure of the projected food supply is then as follows: the total calorie projection is apportioned to each of the food groups by their projected ratios, which are in turn apportioned to the projected commodity ratios. Hence by combining equations 1,2 and 3 , the number of calories contributed to the mean daily food supply per capita by commodity $j$ (of group $i$ ) is

$140 \quad E_{j}(n)=F(n) * P_{i}(n) * P_{j}(n)$,

where all symbols have their previously defined meanings. This approach facilitates the tuning of dietary scenarios by modifying the growth rate of the animal product group or dairy commodities to simulate increases in vegetarianism or veganism.

\subsection{Food system efficiency}

\section{$145 \quad$ 3.2.1 Agricultural industrialisation parameter}

There is significant variation in food-system efficiency, both at different stages and between developed and developing food systems. To reflect this in C-LLAMA, a parameter was developed to assign areas an appropriate degree of efficiency at each stage of the food system and in the model processes. The requirements of the system are the following:

1. Allow the food system efficiency of states to improve as the model progresses.

2. Limit improvement to a realistic maximum.

3. Be representative of most real-world cases. Outliers are inevitable but significant contributors of food demand or food production to the global food system should be captured well.

A highly developed nation in which the majority of farming practices are heavily industrialised with high levels of efficiency should have a score of greater than 1.0 whilst a less developed country in which the majority of people are fed through subsistence farming should score lower than 0.5. A metric such as GDP per capita is not suitable, because a state with extreme income equality could score highly when in actuality the majority of inhabitants rely on subsistence agriculture. Other metrics such as irrigation, fertiliser use and agricultural machinery density were all considered. However, each of these metrics can be skewed by climate, crop types and traditional practices. As such these are also not always reflective of the relative agricultural efficiency of an area.

160 A parameter was developed based on the yearly mean of daily food energy consumption per capita. This is a self-moderating quantity: unlike GDP there is a maximum realistic value that this can take regardless of economic disparity, so the mean cannot be skewed by extreme cases. The equation for the agricultural industrialisation parameter $X$ for a country $a$ in year $n$ is

$X_{a}(n)=\frac{F_{a}(n)}{F_{\text {target }} * 0.7}-\frac{0.5}{0.7}$ 
where $F$ is the country's total food supply in year $n$ and $F_{\text {target }}$ is the idealised food supply defined in section 4.1. Using the ratio of food supply to an idealised food supply generates values in the approximate range 0.5 to 1.2 . The values 0.5 and 0.7 scale the metric to produce values for $X_{n}$ in the range 0.0 and 1.0.

This parameter is then projected forward with a simple linear projection to 2050 for use in the model processes. In the very few cases where the projection prescribes a decline in industrialisation, the parameter is halted at the most recent historic value. In the majority of cases this parameter reasonably depicts the position of a country along a scale between complete subsistence agriculture to complete agricultural industrialisation. However, due to the complexity of the real-world food system, there are a small number of expected outliers, notably Japan and the Republic of South Korea, both of which score in the range 0.4 to 0.6 , much lower than expected given their level of industrialisation. This can be explained by a combination of two factors: a slightly lower post-production food waste of around 15\% (Liu et al., 2016) and typically a lower daily calorific intake than other similarly industrialised nations; a result of cultural and dietary trends (Tsugane and Sawada, 2014).

175 The parameter is used in the model processes to inform processes relating to agricultural efficiency, including food energy losses at three stages: harvest, distribution, and post-production losses. Minimum and maximum values are chosen for each, representing either the totally subsistence or total industrialised case, and the metric is used to scale the value for a country between the two. The equation for a factor $\mu$ is:

$\mu_{a}(n)=\mu_{\text {sub }}+X_{a}(n)\left(\mu_{\text {ind }}-\mu_{\text {sub }}\right)$

180 where $X$ is the value of the agricultural industrialisation parameter for the country $a$ in given year $n$ and $\mu_{\text {sub }}$ and $\mu_{\text {ind }}$ are the subsistence or industrialisation boundaries of the factor respectively. The upper and lower boundaries for each of these parameters can be modified as a means of scenario adjustment. The behaviour of the boundaries as the model progresses can also be modified; they can be fixed at the initial values, or an overall efficiency increase can be prescribed, in which case the limits will also change over time.

\subsubsection{Inefficiency in the food system}

In C-LLAMA, losses in the food system are grouped in four ways: losses at the harvest stage, losses in the processing stage, distribution losses and post-production losses.

Losses at the harvest stage occur before any processing or distribution and are either non-recoverable or recoverable. Causes of non-recoverable losses include insect and animal pests, weeds, and disease. Developing regions see greater losses during production than developed regions due to the availability of disease and pest prevention measures (Oerke and Dehne, 2004; Savary et al., 2012). Losses due to these factors are accounted for in crop-yield data so no loss factor is applied at this stage. The methodology for handling recoverable harvest losses: 'harvest residues', is more complicated since these are crop dependant. Not all harvested material is edible for humans, for example the husks and casings or 'chaff' produced when harvesting grains. The formalisation of this concept is the harvest index, defined as the ratio of the mass of useful product to the mass of above ground biomass (Singh and Stoskopf, 1971). Despite being an inefficiency in the food system, many waste products produced at the harvest stage can be used for other purposes to reduce this inefficiency. Chaff for example, while 
inedible to humans, is suitable feed for most livestock. Harvest residue indices and harvest residue recovery rates are used to inform a ratio of produced residue to recovered residue (Wirsenius et al., 2010; Krausmann et al., 2008). Tables of harvest residue indices and recovery rates can be found in appendix A.

Processing losses occur as the raw crops are processed to a form suitable for their intended purposes, for example the removal of kernels from olives. Some of these losses are potentially recoverable for use as animal feed, bioenergy feedstock or in other industries (Van Dyk et al, 2013). Fodder crops generally incur less loss than crops destined for human consumption at the processing stage as they require little to no processing (Kitinoja, 2013; Gustavsson and Cederberg, 2011).

Distribution losses are incurred through transportation or storage. This stage is a major contributor to food system inefficiency in developing countries; due to poor road infrastructure, pests and lack of suitable refrigeration or other storage, losses at this stage can be as high as 50\% and as low as 5\% in developing and developed areas respectively (Parfitt et al., 2010; Lipinski et al., 2013).

Post-production food waste refers to food lost at the consumer level, including food thrown away after purchase in the home, or in commercial environments such as restaurants. Unlike most other food system loss factors, the heaviest post-production losses are seen in the developed world (Parfitt et al., 2010; Stancu et al, 2016).

\begin{tabular}{|l|l|l|}
\hline Loss factor & Industrialised (1.0) & Subsistence (0.0) \\
\hline Processing & $6 \%$ & $10 \%$ \\
\hline Distribution & $5 \%$ & $50 \%$ \\
\hline Post-production & $30 \%$ & $5 \%$ \\
\hline
\end{tabular}

Table 2. Boundary values for loss factors informed by the agricultural industrialisation parameter.

\subsection{Food production}

\subsubsection{Production}

Following the application of the loss factors determined in the food system efficiency section to the food supply projections described in section 4.1, each country is left with a food energy requirement for each food commodity, $r$, calculated using the following equation:

$r_{j, a}(n)=E_{j, a}(n) * \prod_{l \in L} \mu_{l, a}(n)$,

where $r$ is the energy demand from a country $a$ for commodity $j, \mu$ is a loss factor and $L$ is the set of processing, distribution, and post-processing losses. $E$ is the calorific contribution to the country food supply from commodity $j$, described in section 4.1. The food energy lost due to efficiency loss factors is retained for potential re-use as livestock feed. Food demand is then summed globally for each key commodity or commodity group is, so the global production requirement $R$ for the commodity $j$ is

$R_{j}(n)=\sum_{a \in A} r_{j, a}(n)$,

where $r$ is the food energy demand for commodity $j$ from a country $a$, and $A$ is the set of all countries. 
C-LLAMA does not have a formal representation of trade, instead trade is implicit in the allocation of food production; global proportions of production for each crop commodity are calculated using the most recent five years of production data then allocated accordingly. For example, the USA was responsible for 42\% of global wheat production between 2012 and 2017 , thus $42 \%$ of all wheat production in C-LLAMA is allocated to the USA. Following this process, each nation is left with a production allocation for each key commodity and commodity group, the equation for which is

$q_{j, a}(n)=\frac{M_{j, a}}{\sum a \in A M_{j, a}} * R_{j}(n)$

where $q$ is the allocated production energy of commodity $j$ in the country $a, M$ is the mean of the most recent five years of historical production mass of commodity $j$ in country $a$ and $A$ is the set of all countries.

\subsubsection{Crop yield}

A large proportion of yield variation can be explained by climate variability, with the remainder being a result of farming practices and industrialisation (Mueller et al., 2012; Ray et al., 2015). C-LLAMA takes largely the same approach as FALAFEL; historical yields for each crop and group are projected linearly to 2050, but this is done for each country. Yield has the potential for large transient variation on a year by year basis, often a result of climate events, pests or management (Frieler et al., 2017; Ray et al., 2015). Consequently, there is the possibility of yields increasing at an unrealistically high rate through this kind of projection. To address this, in C-LLAMA yields are capped at the historical maximum value for a region, preventing any region from exceeding an observed value whilst allowing each country within a region to catch up to a localised observed maximum. Linear projections with a p-value greater than 0.05 (this threshold can be changed) or a decreasing yield are discarded. In either of these cases, the mean yield from the previous ten years of data is used instead.

For all key crops the raw yield data, in tonnes per hectare per year, was used to make the projection. In the case of grouped crops, the groups yield was calculated by taking mean of all crops contained in the group, weighted by national production mass. The group 'sugar crop' consists almost entirely of sugar beet since sugar cane is represented as an individual crop. For palm oil, vegetable oils and other oil_crops, an effective oil yield was calculated for each using their respective oil factors which can be found in the FAOSTAT database (Food and Agriculture Organization of the United Nations, 1997).

\subsection{Livestock}

Animal product demand is the highest contributor to agricultural land demand and greenhouse gas emissions globally and as such livestock are a crucial component of the C-LLAMA model (Van Zanten et al., 2018; Pikaar et al., 2018). As with vegetal food commodities, livestock commodities are partially grouped, with major commodities: bovine meat, pig meat, mutton/goat meat and poultry meat remaining separate. The remaining meat products contribute comparably little to the global demand for animal products and are grouped into an 'other meat' category. Eggs, dairy and fish are each in their own groups. For each country, an animal commodity demand is produced per year in the diet and food supply section of the model. As is well established, livestock are inherently less resource efficient than vegetal products as a means of providing calories for human 
consumption. The feed consumed by livestock does not go directly to become fresh animal product, instead much of it supports the survival of the animal. This is commonly quantified as a feed conversion ratio (FCR) or livestock conversion efficiency (LCE), expressed as the quantity of feed energy or mass to fresh animal product mass or equivalent energy. This number varies drastically between animal product types: bovine meat has an energy FCR of approximately $3 \%$, whereas poultry meat is much higher at 21\% (Shepon et al., 2016). Note that these FCRs are produced from data acquired in the USA. Currently the values used in C-LLAMA are taken from FALAFEL; a cohesive energy-equivalent FCR dataset was not found at a regional or country level. FCRs certainly do vary regionally, largely due to the different role of livestock in different food systems. A cow in a subsistence agriculture environment is more likely to be allowed to live to substantial age, providing dairy and driving machinery. This contrasts with a cow in industrialised agriculture, where it might be reared solely for meat and slaughtered in early adulthood (Wirsenius et al., 2010). A proportion of livestock feed demand is met through forage ( $\left.\mu_{\text {forage }}\right)$ and the remainder is met through feed and residues ( $\mu_{\text {non-forage }}$ ). The proportion of demand met with fodder and residues $(z)$ is calculated using the agricultural industrialisation parameter to assign a value between the subsistence case and the industrialised case, using the same method as in Eq. (6). The quantity of feed demand energy from non-forage $D$ for animal product $j$ in country $a$ is

$D_{j, a}(n)=Q_{j, a}(n) * \mu_{\text {non-forage } j, a}(n) * \mathrm{FCR}_{j}$,

where $\mathrm{FCR}_{j}$ is the livestock dependant feed conversion ratio and $q$ is the production allocation. The extreme cases for each animal product are centred around the FALAFEL numbers, with the developing limit being $20 \%$ lower and the developed limit being 20\% higher. The proportion also varies dependant on the animal product, for example chickens and pigs typically obtain a higher proportion of their food energy from feed than ruminants (Tufarelli et al., 2018). An individual animal will likely be fed through a combination of forage and feed, but for the purpose of the model the assumption is made that the land footprint of non-forage comes only from the land required for fodder crops. This approach is coarse compared with modelling livestock as entities with individual mixed feed demands, however the feed energy requirements are comparable.

\subsubsection{Waste and residues as feed}

In some situations, livestock can utilise waste from the agricultural system, processing losses, post-production food waste and

harvest residues. For each livestock commodity a potential feed ratio for each of these waste streams is estimated: the maximum proportion of each waste type that could contribute to the livestock diet (z). These ratios can be found in appendix A. Waste produced by processing, distribution and post-production are calculated at the country of consumption, while harvest residues are calculated at the crop production stage. Post-production waste is assumed to only be available to animals in the area in which it was produced and is informed by a post-production waste to feed factor $\left(\mu_{\text {post }}\right)$, scaled by the agricultural industrialisation parameter using Eq. (6) between $40 \%$ and 5\% for the subsistence and industrialised cases respectively. Note that in the case of post-production waste the subsistence extreme is 'more efficient' than the industrialised case. The remaining total available waste energy is multiplied by an other waste to feed factor $\left(\mu_{\text {other }}\right)$, again informed by the agricultural 
industrialisation parameter using Eq. (6), with the subsistence and industrialised limits being $15 \%$ and $40 \%$ respectively. These numbers are taken from the low and high efficiency scenarios in FALAFEL. Waste energy is 'fed' to livestock, up to the potential feed ratio limit, allocated by the potential feed ratios $(z)$. The energy used is then subtracted from the livestock feed energy demand, the remainder of which is accounted for with fodder crops. The remaining feed energy demand to be met through fodder crops $\left(D^{\prime}\right)$ is

$D_{j, a}^{\prime}(n)=\sum_{\omega \in \Omega}\left[\left(D_{j, a}(n) *\left[1-z_{j, \omega}\right]\right)-S\left(D_{j, a}(n) * z_{j, \omega}-\left[w_{\omega}(n) * \mu_{\omega} * \frac{z_{j, \omega}}{\sum_{c \in C}\left(z_{c, \omega}\right)}\right]\right)\right]$

$S(x)= \begin{cases}x & x>0 \\ 0 & x \leq 0\end{cases}$

where $D$ is the total feed energy demand, $z$ is the maximum portion of feed energy that livestock $j$ can obtain from waste stream $\omega, w$ is the available waste energy and $\mu$ is the waste to feed factor. $C$ is the set of all livestock commodities and $G$ is the set of all waste streams: post-production, processing, and harvest residues. $\mu$ is $\mu_{\text {post }}$ for post-production waste and $\mu_{\text {other }}$ for all other waste streams.

\subsubsection{Fodder}

300 Following the reduction of livestock feed demand through waste to feed and foraging, the remaining feed energy demand is met with fodder crops. The historical fodder mix, the ratio of each crop making up fodder in a country, is calculated using the most recent five years of 'feed' energy data in the FAOSTAT food balance sheets. The cereals contributing the most to the fodder mix globally are maize, wheat, sorghum, barley and rice. In addition, soybeans, potatoes, cassava, pulses and fruits also contribute in the top ten. Each of these products are represented individually while all other products used as feed are grouped

305 as 'other feed'. Around $8 \%$ of the total feed mass each year comes from non-crop products. The majority of this $8 \%$ is milk and the remainder is largely comprised of aquatic products such as fishmeal and aquatic plants, often added to livestock feed to supplement nutrition (Holman and Malau-Aduli, 2013; Oliveira Vieira et al., 2015). These products are removed from the fodder mix, as these products require minimal additional land. The remaining livestock feed demand is split according to the derived fodder mix, so the contribution to the total fodder requirement $(r)$ in country $a$ from fodder product $k$ is

$r_{k, a}(n)=\frac{f_{k, a}}{\sum_{s \in S} f_{s, a}} *\left(1-\frac{f_{\text {milk }, a}+f_{\text {aq }, a}}{\sum_{s \in S} f_{s, a}}\right) * \sum_{c \in C}\left(D^{\prime}{ }_{c, a}\right)$,

where $f$ is the five year mean of feed data for fodder product $k$ from the FAOSTAT food balance sheets, $f_{\text {milk }}$ and $f_{\text {aq }}$ are the feed data for milk products and aquatic products respectively, $S$ is the set of all fodder products. $D^{\prime}$ is the fodder demand for livestock commodity $c, C$ is the set of all livestock commodities. The global production requirement for fodder product $k$ is then

$315 R_{k}(n)=\sum_{a \in A} r_{k, a}(n)$.

In the same way as crop production for food, the fodder crop production demand is allocated based on historical production of the fodder products. The production allocation $(q)$ for fodder product $k$ for country $a$ is 
$q_{k, a}(n)=\frac{M_{k, a}}{\sum_{a \in A} M_{k, a}} * R_{k}(n)$,

where $M$ is the five year mean production mass for fodder product $k$ and $A$ is the set of all countries. In the case where the product has been considered as a food commodity and thus a yield and production allocation has already been calculated, the additional production allocation for fodder is simply added to the nations existing production quota of the commodity for food. In some cases, it is necessary to perform a yield projection in the same manner as described in section 4.3. Following this stage, each country has a production quota for each year for each commodity, used for food, animal feed, or both, along with a corresponding yield trajectory.

\subsection{Land use}

\subsubsection{Crop land use}

Combing national crop yield projections and production allocation produces a yearly land demand trajectory for each crop within a given country. Since the model objective is to explore sensitivities rather than absolute land-use values, land-use is projected from the most recent value in the FAOSTAT data. In the case that total land demand for crops is less than the previous year, the land difference between the years is put into a 'freed land' class. In FALAFEL this land is then used for either afforestation or energy crops, while C-LLAMA does not currently process this further. In reality land use change is multidimensional; the abandonment of agricultural land varies greatly between areas and industrialisation levels, influenced by climate, land productivity, tradition and governance (Lambin and Meyfroidt, 2011; Lambin et al., 2003). C-LLAMA currently does not consider non-agricultural land use. Further development to include more complex handling of land-use is intended.

\subsubsection{Livestock land use}

As mentioned in section 4.4, the land requirements for livestock in C-LLAMA come entirely from their pasture area; the implication being that all fodder fed animals are under roof, while their foraging counterparts graze pasture. This is generally not the case for foraging pigs and chickens, so a pasture factor $(z)$ of 0.1 is applied to reduce their land footprint from that of cows and sheep (Tufarelli et al., 2018).

The land used for livestock pasture is calculated using an effective pasture yield. First, the historical energy obtained from pasture by livestock was estimated using a similar process to the method adopted in Haberl (2007); for each country, available feed is subtracted from a livestock feed demand, calculated using historical production energy and feed conversion ratios. This leaves animal food acquired through forage. Dividing this quantity by land-area used for pasture in a given year results in the 345 historical effective pasture yield - animal product energy produced per hectare of pasture. The historical effective pasture yield $(Y)$ for animal products in country $a$ is

$Y_{a}=\frac{1}{L_{\mathrm{pasture}, a}} *\left(\sum_{j \in J}\left[M_{j, a} * \mathrm{FCR}_{j} * Z_{j}\right]-\sum_{k \in K} f_{k, a}\right)$, 
where $L_{\mathrm{pasture}}$ is the country's pasture land area, $M$ is the production mass of an animal product $j, \mathrm{FCR}_{j}$ is the feed conversion ratio for the animal product and $J$ is the set of animal products. $f$ is the quantity of available feed product $k$ and $K$ is the set of all feed products. The historical trajectory is linearly projected to 2050, then combined with the production mass demand for each livestock commodity. As with crop land-use, the trajectory is scaled to the most recent FAOSTAT value for each country. Instead of scaling the land-use however, the effective pasture yield is scaled. The scaling is calibrated to an anchor scenario described in section 5 to address counter-intuitive model behaviour, discussed in appendix C. This method is coarse but offers a catch-all method of translating a production demand into land-area for every country in C-LLAMA.

\section{Model output}

C-LLAMA produces a land-use trajectory to 2050 for each food commodity and commodity group within a country, output as a comma separated variable file. Animal product land-use is aggregated as pasture, explained in section 4.4. All crops have individual land-use trajectories. An output with crops aggregated into either crops or specifically fodder crops is also produced. Data from intermediate stages of the model such as food supply and crop yield projections is retained upon completion of the model run, but for the sake of storage space is stored in a serialised format using the 'pickle' library, part of the Python standard library (Van Rossum and Drake Jr, 1995).

\subsection{Anchor Scenario}

C-LLAMA is based around an anchor scenario, in which all parameters take default values based on literature and projections from historical data are made to 2050. This scenario aims to be as close an approximation to the real world as possible in the

365 framework of the model, with targets for efficiency and industrialisation being set at middle of road values. Table B1 in shows key parameters and their values in the anchor scenario.

Figure 4 shows agricultural land-use at the continental level for historical FAOSTAT data and in the C-LLAMA anchor scenario. All continents see an increase in land-use for both crop and animal production, with the rate of increase slightly decreasing toward 2050. The greatest rate of increase occurs in Asia and the least in Africa and Europe. Oceania and the

370 Americas have comparable trajectories. In all cases, the rate of increase for pasture is greater than that of cropland, with cropland for fodder crops lying in between. The direction of the projected land-use aligns with that of the historical data in the Americas, Africa, and Asia. However, in Europe and Oceania a slight reversal of the direction of change occurs. 


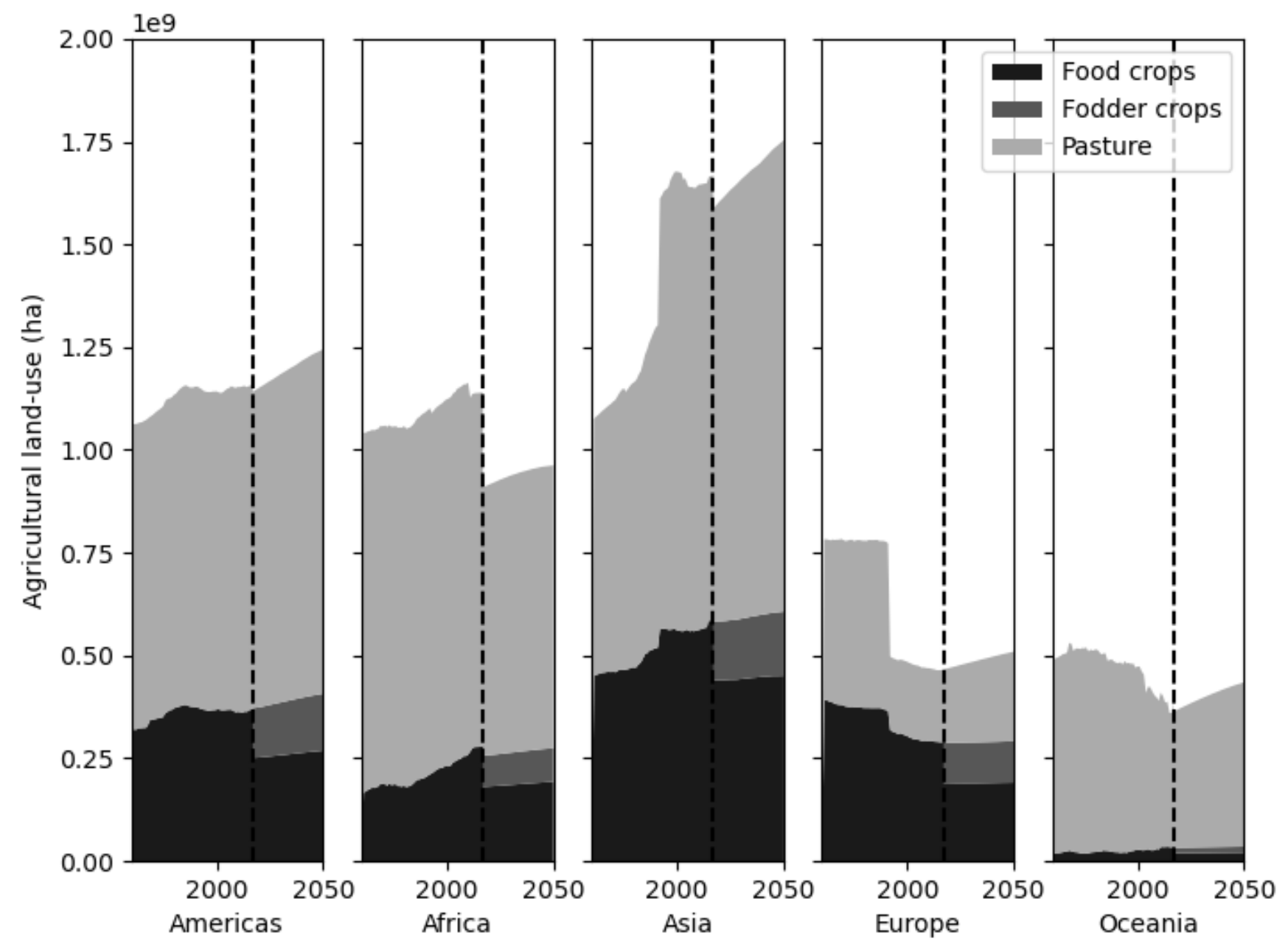

Figure 4. Agricultural land-use in FAOSTAT historical data and C-LLAMA anchor scenario projection for five continental regions. The transition from historical to modelled data is denoted by the dotted black line. Discontinuity at the dotted line is due to the countries not included in C-LLAMA for various reasons described in section 3. 99.7\% of this discrepancy is the result of unavailable food balance data for Libya, Somalia, Sudan, the DRC, and Papua New Guinea. Also note the sudden increase of land-use in Asia and corresponding decrease in Europe in the early nineties, the result of the dissolution of the Soviet Union. As the FAOSTAT land-use does not contain disaggregated crop-data for fodder and food, food crops also include fodder crops in the historical data.

Figure 5 shows the projection of mean diet at the continental level in the C-LLAMA anchor scenario. All continents undergo an increase in total calorific intake toward 2050, except for Europe which sees decrease in calorific intake of approximately $200 \mathrm{kcals}$. Europe is also the only continent to start above the idealised food supply of $3200 \mathrm{kcal}$, described in Section 4.1. The demand for animal products increases in across all continents, although only very slightly in Europe and Oceania. The 
consumption of cereals increases in Africa and Oceania, is unchanging in the Americas, and decreases strongly in Asia and Europe with a drop of 200 and $300 \mathrm{kcal}$ by 2050 respectively. The demand for oil crops sees similarly proportional increases in every continent, with the Americas, Europe and Oceania consuming more.
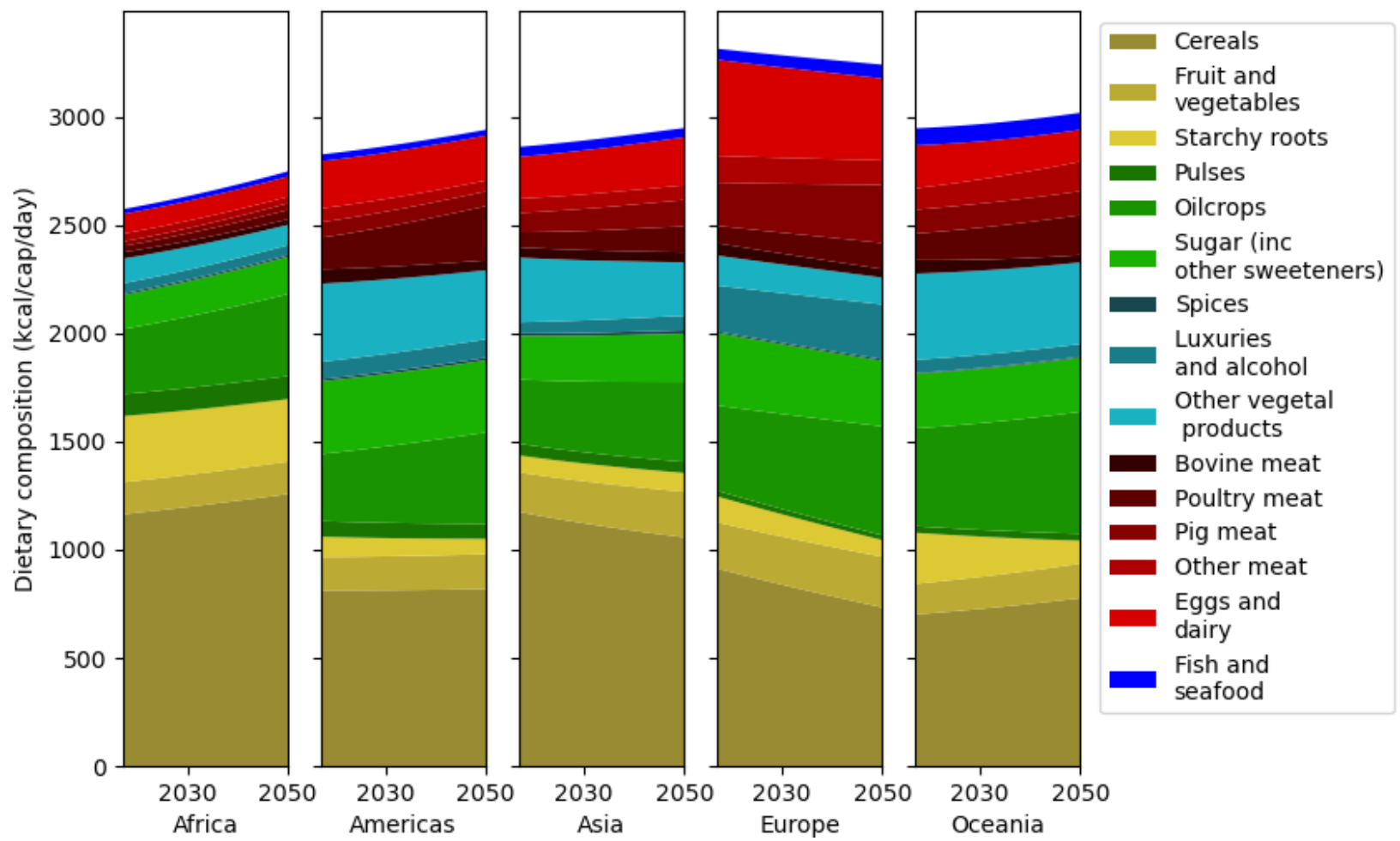

Figure 5. Calorific mean diet composition at the continent level for the C-LLAMA anchor scenario. Some food commodities are grouped for clarity and the order of appearance from the origin for the groups aligns with the legend.

\subsubsection{Comparison with FALAFEL}

The globally summed land-use output of the C-LLAMA anchor scenario can be compared with the land-use trajectory of an analogous business as usual scenario produced in FALAFEL. In the same way as C-LLAMA, the FALAFEL model allows prescribed increases in efficiency - for example a forced reduction in animal product consumption. To produce the business as usual scenario in FALAFEL, linear projections are made where they are available and all prescribed efficiency changes are turned off. For comparison, the land-use data from both models is grouped into pasture, food crops (for human consumption), and fodder crops. The resulting land-use for both modelled scenarios is shown in Fig. 6. The trajectory of both the FALAFEL scenario and the C-LLAMA anchor scenario reach just over 5 Gha by around 2050. The difference in starting food crop area is indistinguishable between the models, however a small amount of additional growth occurs by 2050 in C-LLAMA. CLLAMA starts with a greater area of fodder crops but sees less growth by 2050 than in FALAFEL. The largest difference lies 
in pasture, with C-LLAMA starting at just over 3 Gha and FALAFEL starting at around 2.6 Gha, although both models have approximately 3.5 Gha of pasture by 2050 .
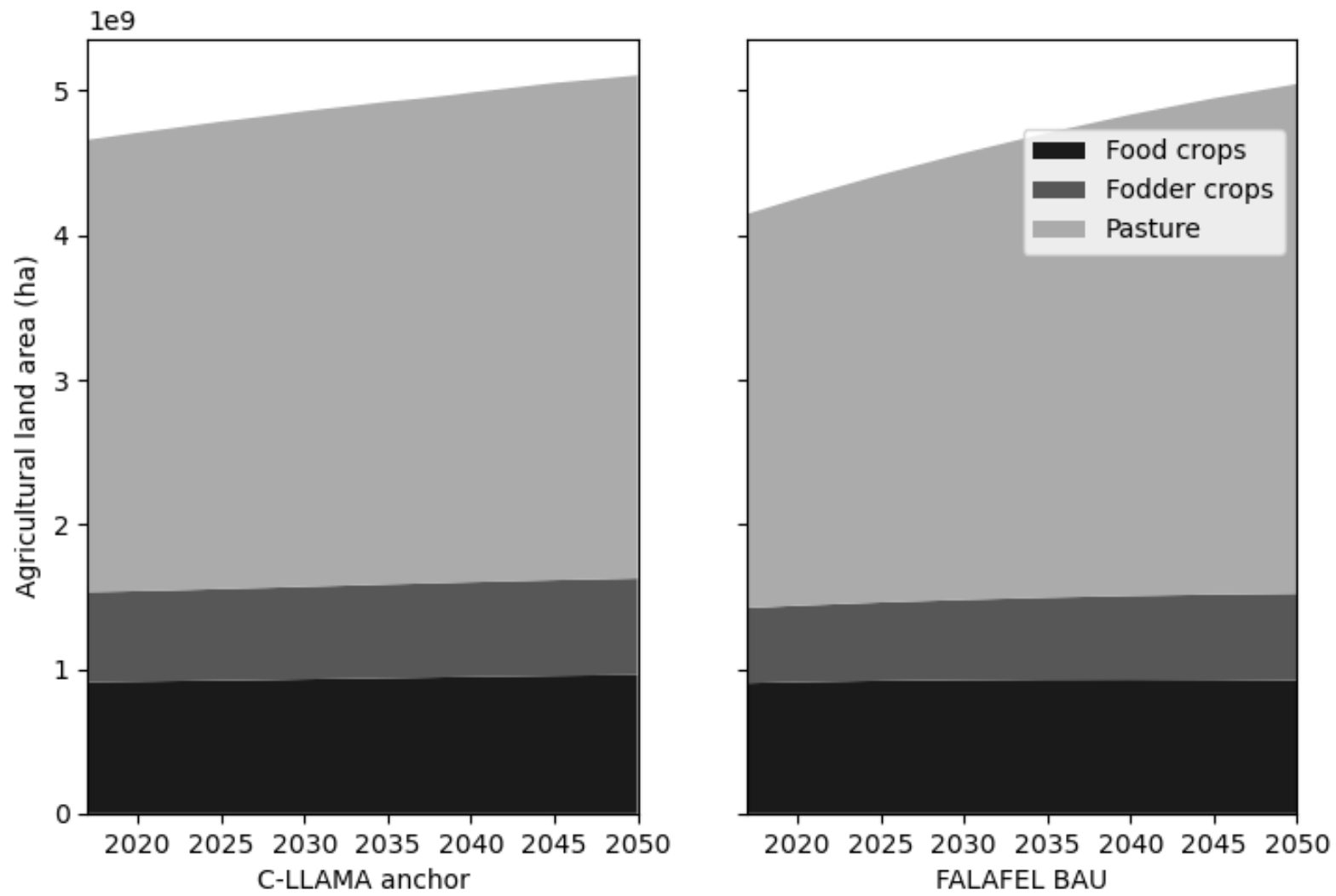

Figure 6. Aggregated global land-use for food production in the C-LLAMA anchor scenario and a 'business as usual' (BAU) FALAFEL scenario. FALAFEL accounts for the production of some non-food crops, however they are excluded for this comparative figure.

A comparison of the global diet projections for both the C-LLAMA anchor scenario and the FALAFEL business as usual scenario is shown in Fig. 7. The difference between the two scenarios is slight; in C-LLAMA fish contributes slightly more to 410 the average diet than in FALAFEL, with animal products in general also contributing slightly more by 2050. 

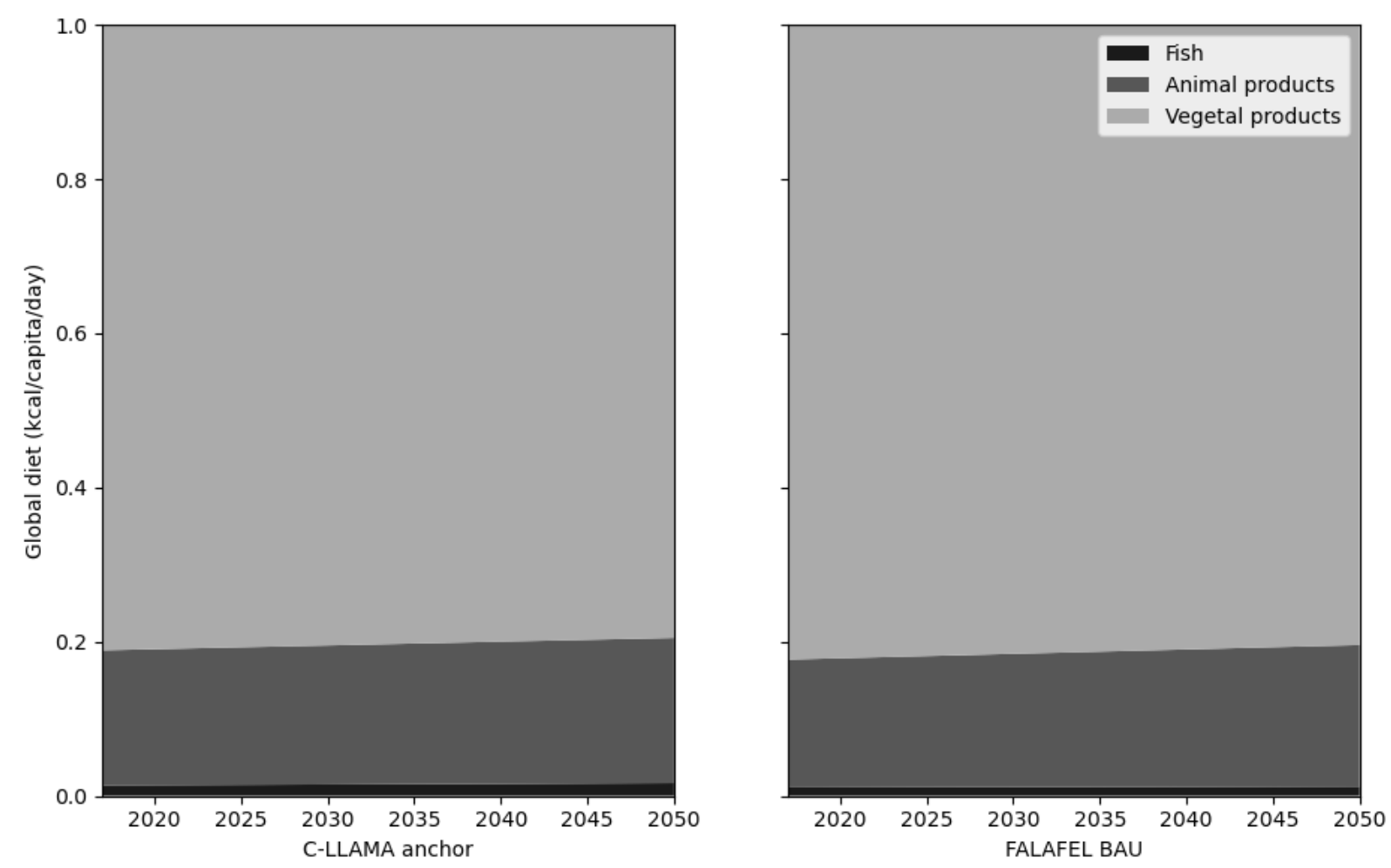

Figure 7. Proportion of mean food group contributions to total diet for the C-LLAMA anchor scenario and the FALAFEL BAU scenario.

\subsection{Sensitivity}

415 Four key projections are made throughout the course of the model for each country. Diet and crop yields are projected directly from the historical data, whereas the agricultural industrialisation parameter and effective pasture yield are internal values calculated from historical data, which are then projected. To explore the sensitivity of the final land-use output of C-LLAMA to these four projections, each was fixed at the mean value of their most recent five years and the land-use by 2050 compared with the anchor scenario. The results of this are shown in Fig. 8. 


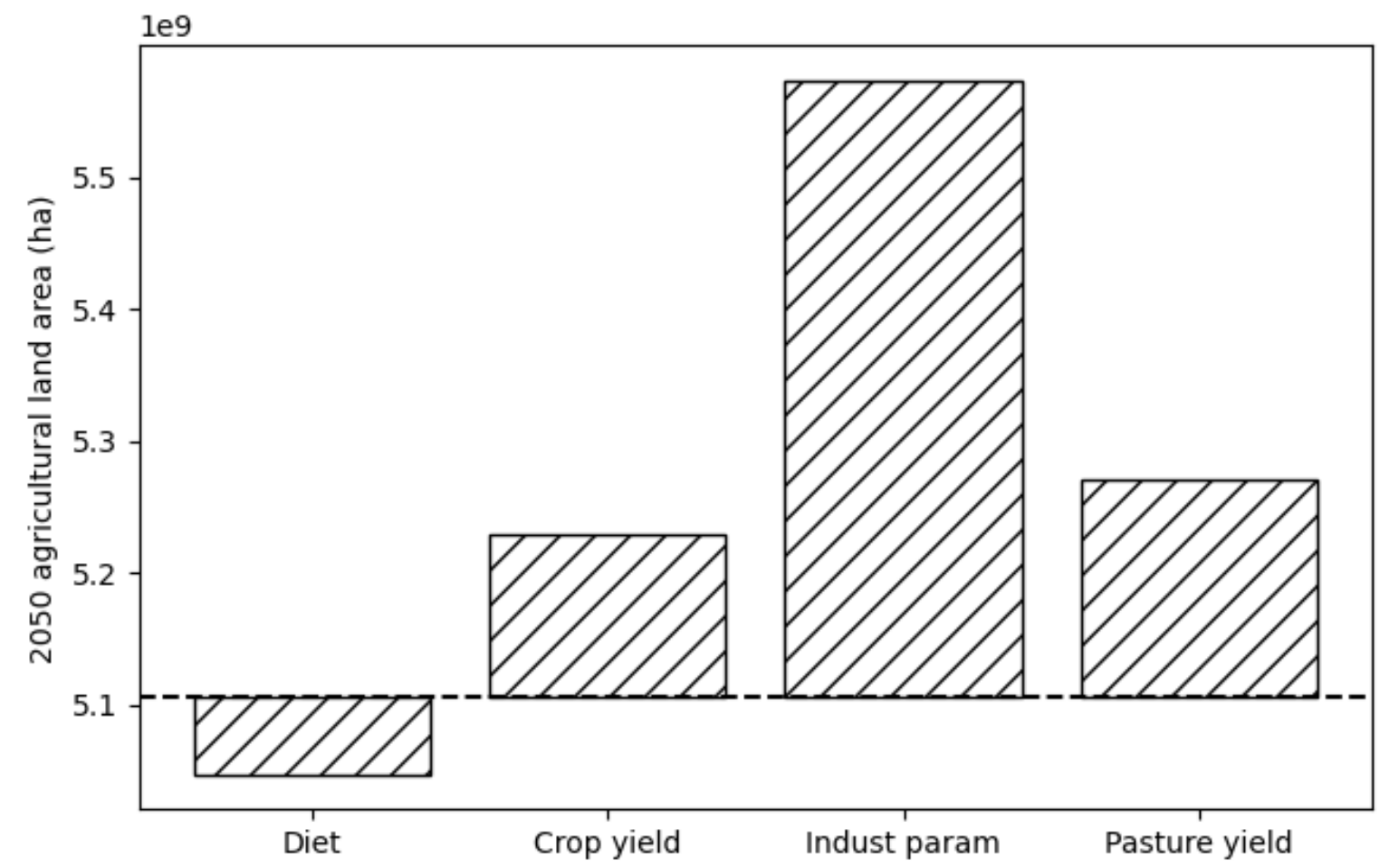

Figure 8. Difference in 2050 global agricultural land-use between the anchor scenario (dotted line) and when disallowing the progression of projections in the model by using the $\mathbf{5}$ year mean of historical values for each.

The impacts of each of these projections are within an order of magnitude of each other. Halting the projection of crop yields results in an increased agricultural land-use of just over 100 Mha from the anchor scenario. This is consistent with the current trend of increasing crop yields in most areas of the world: a result of improved access to irrigation, agrochemicals and machinery (Iizumi et al., 2017; Ray et al., 2012). Suspending the projection of the agricultural industrialisation metric has the greatest impact on the total land-use with an increase of approximately $450 \mathrm{Mha}$. Suspending the agricultural industrialisation metric locks many countries in a state of lower efficiency, unable to meet the increasing food demand from the growing population. Halting changes in pasture yield leads to an increase in land-use of around 150 Mha. While the 'effective pasture yield' is not a real-world quantity, it aims to capture a wide range of factors that govern the output of grazed land. This quantity is increasing in the majority of countries, the result of livestock intensification by transfer to more intensive pasture or a covered system (Thornton, 2010; Davis and D'Odorico, 2015). Stopping the projection of dietary trends reduces the final land-use by $50 \mathrm{Mha}$. Current global dietary trends are toward increased animal product consumption in developing countries and stagnation of animal product consumption in developed nations (Van Zanten et al., 2018; Tilman and Clark, 2014). Coupled with the prescribed trajectory toward an idealised diet, leading to an increase in calorific intake in the majority of countries, this explains the decrease in land-use when suspending the projection of diet. 
Loss factors in C-LLAMA are dynamic, governed by the agricultural industrialisation metric. To explore the sensitivity of the model to loss factors every country was fixed at the lower and upper boundary values, equivalent to scoring every country at 0.0 or 1.0 respectively on the agricultural industrialisation metric. Figure 9 shows the results of this analysis. An increase in 440 efficiency leads to a land-use reduction of approximately 900 Mha by 2050, and a decrease in efficiency leads to a drastic increase of just under 3000 Mha by 2050. The present efficiency scenario is achieved by halting the agricultural industrialisation parameter, identical to the 'indust param' scenario in Fig. 8. The greater sensitivity to decreased efficiency is a result of the distribution of agricultural industrialisation scores: more countries score higher than 0.5 than lower, hence setting all countries to 0.0 is a greater 'shift' than setting all countries to 1.0. The magnitude of these changes is significantly larger 445 than those seen in Fig. 8.

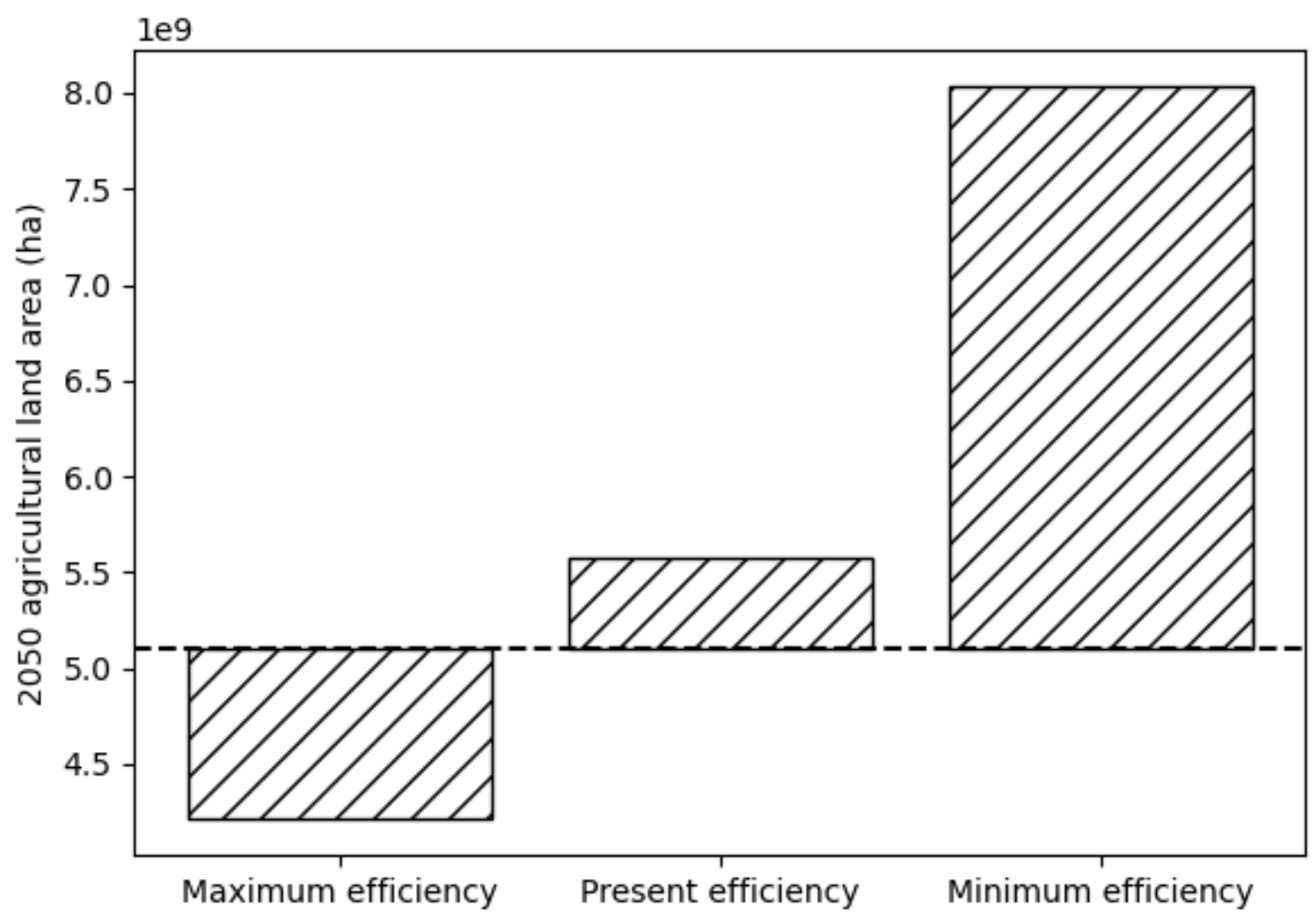

Figure 9. Change in 2050 agricultural land-use between the anchor scenario (dotted line), maximum, present, and minimum efficiency scenarios. Maximum and minimum efficiency scenarios are produced by setting the agricultural industrialisation metric to 1.0 and 0.0 respectively for all countries. 


\section{Discussion}

\subsection{Limitations}

The strength of C-LLAMA lies in its simplicity: it can be easily modified, adapted, and improved. However, there are limitations to the approach and two key areas for improvement have been identified. One area with scope for improvement is in the allocation of crop and livestock production described in section 4.3. The current method uses a snapshot of current production to distribute the projected production of a crop; this approach works for earlier projected years since interannual changes to trade are relatively slow, being on similar timescales to changes in demand. However, long term changes to global trade are not captured, specifically those likely to arise from improved access to wealth and subsequent demand for luxury and animal products in developing countries. Improvements might include trade matrices for each food commodity, or projection of the commodity production allocation, which would allow dynamic trade representation without the need for any agent based or economically driven modelling. The other area with great potential for improvement is the representation of livestock and, more broadly, land-use within the model. The current method for estimating land-use for crops and livestock is effective for exploring questions surrounding global-scale changes and scenario options. However, a land class system with productivity, land-use transitions, and associated carbon exchange would facilitate a more nuanced exploration of the drivers of land-use and their consequences, particularly in the case of livestock, forests, and grasslands.

465 Including the DRC, Libya, Sudan, Somalia, and Papua New Guinea would be beneficial as together they account for a significant portion of the global land area (approximately 3\%). Papua New Guinea and the DRC have humid, equatorial climates with highly productive land; excellent conditions for agricultural productivity (Kottek et al.; 2006). While not included in the food balance data, they are present in other FAO data, so it may be possible to construct an approximate food balance dataset from their available FAO data and regional averages. Another approach would be to construct food balances using other data sources, however this approach would contravene the internal consistency of C-LLAMA.

\subsection{Applications}

C-LLAMA takes a simple approach to modelling the drivers of land availability, offering transparency and adaptability where many other, more complex modelling approaches do not. Of the many drivers of future land-availability, the simplicity and traceability of the model make it well placed to explore the impacts of broad scale drivers such as changes in livestock production systems, crop yields, dietary trends and food system efficiency on the future of land available for food agriculture, bioenergy and afforestation from a bottom-up perspective. The model aims to be easily accessible to use and modify, using only open source data and software. 


\section{Appendix A}

\section{Food commodity groupings}

Table A1. Vegetal products and grouped vegetal products. Grouped products do not contain any products represented as staple products. The luxury group consists of tea, coffee and cocoa. The alcohol group consists of wine, beer, 'fermented alcoholic beverages' and 'other alcoholic beverages'. Cereals, fruit and vegetables used in the production of alcoholic beverages are not included in their respective groups.

\begin{tabular}{|c|c|}
\hline Individual products & Grouped products \\
\hline Wheat & Cereals \\
Rice & Fruits \\
Maize & Vegetables \\
Palm Oil & Pulses \\
Rape and mustardseed & Starchy roots \\
Soyabeans & Oil crops \\
Sunflower seed & Spices \\
Potatoes & Sugar crops \\
Cassava & Luxuries \\
Nuts and products & Alcohol \\
& Other vegetal products \\
\hline
\end{tabular}

Table A2. Animal products and groups. In the case of these animal products, the 'individual' animal products represent a small group of products but are dominated by a single product. For example while bovine meat includes derivative products and buffalo, the majority of the bovine meat supply and consumption is formed of cattle meat. There are only two sets of grouped animal products: dairy and 'other meat'. Dairy is a significant contributor to global food supply and demand, but meat products not listed individually do not. Dairy includes milk, butter, ghee and cream. Products such as cheese and yoghurt are also included in the data for milk.

\begin{tabular}{|c|c|}
\hline Individual products & Grouped products \\
\hline Bovine meat & Other meat \\
Poultry meat & Dairy products \\
Pigmeat & \\
Mutton and goat meat & \\
Eggs & \\
\hline
\end{tabular}




\section{Harvest factors and recovery rates}

Table A3a. Vegetal product harvest factors - the ratio of the mass of useful product to above ground biomass. Values

in this table are adapted from from Krausmann et al., 2008. Where a direct mapping was impossible, the average value of other products was used (for example - vegetables). Fruits are assumed to be permanent crops.

\begin{tabular}{|c|c|c|c|c|c|c|c|c|}
\hline & $\begin{array}{l}\text { Sub- } \\
\text { Saharan } \\
\text { Africa }\end{array}$ & $\begin{array}{l}\text { North } \\
\text { Africa } \\
\text { and } \\
\text { West } \\
\text { Asia }\end{array}$ & Europe & $\begin{array}{l}\text { Central } \\
\text { and } \\
\text { Southern } \\
\text { Asia }\end{array}$ & $\begin{array}{l}\text { East and } \\
\text { South- } \\
\text { East } \\
\text { Asia }\end{array}$ & Oceania & $\begin{array}{l}\text { North } \\
\text { America }\end{array}$ & $\begin{array}{l}\text { Latin } \\
\text { America }\end{array}$ \\
\hline Wheat & 2.3 & 1.5 & 1.3 & 1.7 & 1.5 & 1.2 & 1.2 & 1.5 \\
\hline Maize & 3.5 & 3 & 1.6 & 3.5 & 3 & 1.2 & 1.2 & 3 \\
\hline Rice & 1.5 & 1.2 & 1.2 & 1.5 & 1 & 1.2 & 1.2 & 1.2 \\
\hline Soyabeans & 1.5 & 1.5 & 1.4 & 1.5 & 1.2 & 1.2 & 1.2 & 1.5 \\
\hline Potatoes & 1 & 1 & 1 & 1 & 1 & 1 & 1 & 1 \\
\hline Nuts & 1.5 & 1.5 & 1.2 & 1.5 & 1.2 & 1.2 & 1.2 & 1.5 \\
\hline Cassava & 0.8 & 0.8 & 0.8 & 0.8 & 0.8 & 0.8 & 0.8 & 0.8 \\
\hline $\begin{array}{l}\text { Rape and } \\
\text { mustardseed }\end{array}$ & 2.3 & 2.3 & 1.9 & 2.3 & 2.3 & 1.9 & 1.9 & 2.3 \\
\hline Palm oil & 1.9 & 1.9 & 1.9 & 1.9 & 1.5 & 1.9 & 1.9 & 1.9 \\
\hline Sunflower seed & 2.3 & 2.3 & 1.9 & 2.3 & 2.3 & 1.9 & 1.9 & 2.3 \\
\hline Cereals & 2.3 & 1.5 & 1.25 & 1.7 & 1.5 & 1.2 & 1.2 & 1.5 \\
\hline Oil crops & 2.3 & 2.3 & 1.9 & 2.3 & 2.3 & 1.9 & 1.9 & 2.3 \\
\hline Pulses & 0.4 & 0.4 & 1 & 0.4 & 0.4 & 1 & 1 & 0.4 \\
\hline Starchy roots & 1 & 1 & 1 & 1 & 1 & 1 & 1 & 1 \\
\hline Sugar crops & 0.7 & 0.7 & 0.5 & 0.7 & 0.7 & 0.7 & 0.5 & 0.7 \\
\hline Fruits & 2.5 & 2.5 & 2.5 & 2.5 & 2.5 & 2.5 & 2.5 & 2.5 \\
\hline Vegetables & 1.9 & 1.5 & 1.2 & 1.6 & 1.5 & 1.3 & 1.3 & 1.6 \\
\hline Alcohol & 2.1 & 1.5 & 1.3 & 1.7 & 1.5 & 1.3 & 1.2 & 1.5 \\
\hline Spices & 1.1 & 1.1 & 1.1 & 1.1 & 1.1 & 1.1 & 1.1 & 1.1 \\
\hline Luxuries & 0.5 & 0.5 & 0.5 & 0.5 & 0.5 & 0.5 & 0.5 & 0.5 \\
\hline
\end{tabular}




\begin{tabular}{|l|l|l|l|l|l|l|l|l|}
\hline $\begin{array}{l}\text { Other vegetal } \\
\text { products }\end{array}$ & 1.9 & 1.5 & 1.3 & 1.6 & 1.5 & 1.3 & 1.3 & 1.5 \\
\hline
\end{tabular}

Table A3b. Vegetable product residue recovery factors - the recovered proportion of potential harvest residues. As with table A3a, this table is also adapted from Krausmann et al., 2008.

\begin{tabular}{|c|c|c|c|c|c|c|c|c|}
\hline & $\begin{array}{l}\text { Sub- } \\
\text { Saharan } \\
\text { Africa }\end{array}$ & $\begin{array}{l}\text { North } \\
\text { Africa and } \\
\text { West Asia }\end{array}$ & $\begin{array}{l}\text { East } \\
\text { Europe }\end{array}$ & $\begin{array}{l}\text { West } \\
\text { Europe }\end{array}$ & $\begin{array}{l}\text { Central } \\
\text { and } \\
\text { South- } \\
\text { East } \\
\text { Asia }\end{array}$ & $\begin{array}{l}\text { East } \\
\text { Asia }\end{array}$ & $\begin{array}{l}\text { North } \\
\text { America } \\
\text { and } \\
\text { Oceania }\end{array}$ & $\begin{array}{l}\text { Latin } \\
\text { America }\end{array}$ \\
\hline Cassava and products & 0.8 & 0.8 & 0.3 & 0.0 & 0.8 & 0.8 & 0.0 & 0.8 \\
\hline Cereals - Excluding Beer & 0.9 & 0.8 & 0.8 & 0.7 & 0.9 & 0.8 & 0.7 & 0.8 \\
\hline Fruits - Excluding Wine & 0.8 & 0.7 & 0.6 & 0.4 & 0.8 & 0.7 & 0.4 & 0.7 \\
\hline Luxuries (excluding Alcohol) & 0.8 & 0.7 & 0.6 & 0.4 & 0.8 & 0.7 & 0.4 & 0.7 \\
\hline Maize and products & 0.9 & 0.8 & 0.8 & 0.7 & 0.9 & 0.8 & 0.7 & 0.8 \\
\hline Oilcrops & 0.9 & 0.8 & 0.8 & 0.7 & 0.9 & 0.8 & 0.7 & 0.8 \\
\hline Other & 0.8 & 0.7 & 0.6 & 0.4 & 0.8 & 0.7 & 0.4 & 0.7 \\
\hline Palm Oil & 0.9 & 0.9 & 0.9 & 0.9 & 0.9 & 0.9 & 0.9 & 0.9 \\
\hline Potatoes and products & 0.8 & 0.8 & 0.3 & 0.0 & 0.8 & 0.8 & 0.0 & 0.8 \\
\hline Nuts and products & 0.9 & 0.8 & 0.8 & 0.7 & 0.9 & 0.8 & 0.7 & 0.8 \\
\hline Pulses & 0.5 & 0.5 & 0.5 & 0.0 & 0.5 & 0.5 & 0.0 & 0.5 \\
\hline Rape and Mustardseed & 0.7 & 0.7 & 0.7 & 0.7 & 0.7 & 0.7 & 0.7 & 0.7 \\
\hline Rice (Milled Equivalent) & 0.9 & 0.8 & 0.8 & 0.7 & 0.9 & 0.8 & 0.7 & 0.8 \\
\hline Soyabeans & 0.5 & 0.5 & 0.5 & 0.0 & 0.5 & 0.5 & 0.0 & 0.5 \\
\hline Spices & 0.8 & 0.7 & 0.6 & 0.4 & 0.8 & 0.7 & 0.4 & 0.7 \\
\hline Starchy Roots & 0.8 & 0.8 & 0.3 & 0.0 & 0.8 & 0.8 & 0.0 & 0.8 \\
\hline Sugar Crops & 0.8 & 0.8 & 0.3 & 0.0 & 0.8 & 0.8 & 0.0 & 0.8 \\
\hline Sugar cane & 0.9 & 0.9 & 0.9 & 0.9 & 0.9 & 0.9 & 0.9 & 0.9 \\
\hline Sunflower seed & 0.5 & 0.5 & 0.5 & 0.5 & 0.5 & 0.5 & 0.5 & 0.5 \\
\hline Vegetable Oils & 0.8 & 0.7 & 0.6 & 0.4 & 0.8 & 0.7 & 0.4 & 0.7 \\
\hline Vegetables & 0.8 & 0.7 & 0.6 & 0.4 & 0.8 & 0.7 & 0.4 & 0.7 \\
\hline
\end{tabular}




\begin{tabular}{|l|l|l|l|l|l|l|l|l|}
\hline Wheat and products & 0.9 & 0.8 & 0.8 & 0.7 & 0.9 & 0.8 & 0.7 & 0.8 \\
\hline Alcohol & 0.8 & 0.7 & 0.6 & 0.4 & 0.8 & 0.7 & 0.4 & 0.7 \\
\hline
\end{tabular}

\section{Appendix B}

Table B1. Inputs, values and data used to produce the anchor scenario in C-LLAMA.

\begin{tabular}{|c|c|c|c|c|}
\hline \multicolumn{2}{|c|}{ Input } & \multicolumn{2}{|c|}{ Value or data } & Source \\
\hline \multicolumn{2}{|c|}{ Population } & \multicolumn{2}{|c|}{$\begin{array}{l}\text { SSP2 population } \\
\text { trajectory }\end{array}$} & Fricko et al., 2017. \\
\hline \multicolumn{2}{|c|}{$\begin{array}{l}\text { Idealised food supply target } \\
\text { calories }\end{array}$} & \multicolumn{2}{|c|}{3200 (kcal/capita/day) } & $\begin{array}{l}\text { Kearney, 2010; Alexander et al., 2017; } \\
\text { Parfitt et al., } 2010\end{array}$ \\
\hline \multicolumn{2}{|c|}{$\begin{array}{l}\text { Idealised food supply target } \\
\text { year }\end{array}$} & \multicolumn{2}{|c|}{2100} & $\begin{array}{l}\text { Aligns with Paris agreement temperature } \\
\text { goals. }\end{array}$ \\
\hline \multicolumn{2}{|c|}{$\begin{array}{l}\text { Overall efficiency } \\
\text { improvement }\end{array}$} & \multicolumn{2}{|c|}{0.0} & $\begin{array}{l}\text { There is no enforced change to overall } \\
\text { agricultural efficiency in the anchor } \\
\text { scenario. }\end{array}$ \\
\hline \multicolumn{2}{|c|}{ Change to vegetal diet } & \multicolumn{2}{|c|}{0.0} & $\begin{array}{l}\text { No enforced change to portion of food } \\
\text { energy from vegetal products in the } \\
\text { anchor scenario. }\end{array}$ \\
\hline \multicolumn{2}{|c|}{ Change to dairy diet } & \multicolumn{2}{|c|}{0.0} & $\begin{array}{l}\text { No enforced change to portion of food } \\
\text { energy from dairy products in the anchor } \\
\text { scenario. }\end{array}$ \\
\hline \multirow{4}{*}{$\begin{array}{l}\text { Waste factor } \\
\text { limits }\end{array}$} & & Subsistence & Industrial & \multirow[t]{4}{*}{ Refer to section 4.2 and Table 2.} \\
\hline & $\begin{array}{c}\text { Post } \\
\text { production }\end{array}$ & 0.07 & 0.3 & \\
\hline & Processing & 0.10 & 0.06 & \\
\hline & Distribution & 0.5 & 0.05 & \\
\hline \multicolumn{2}{|c|}{ Post-production waste to feed } & 0.40 & 0.05 & \multirow{2}{*}{$\begin{array}{l}\text { Low and high efficiency scenarios in } \\
\text { FALAFEL. (Powell, 2015) }\end{array}$} \\
\hline \multicolumn{2}{|c|}{ Other waste to feed } & 0.15 & 0.40 & \\
\hline
\end{tabular}




\section{Appendix C}

Counter-intuitive behaviour arises when setting the proportion of animals fed through fodder and residues (fed without forage

- FWF) to extreme values. Decreasing the FWF factor (more animals are fed through pasture) leads to an increase in land-use by 2050 . This is expected, as pasture is typically far less land-efficient than housed animals fed through fodder and residues (Pikaar et al., 2018). However, this trend does not continue when the FWF is increased, instead an increased land-use is observed. The behaviour of the FWF prompted further investigation; the factor was scaled by a range of values between 0.5 and 1.5 to observe the behaviour around the default values (a scaling of 1.0), the global agricultural land-use values for which are shown in Fig. $\mathrm{C} 1$.

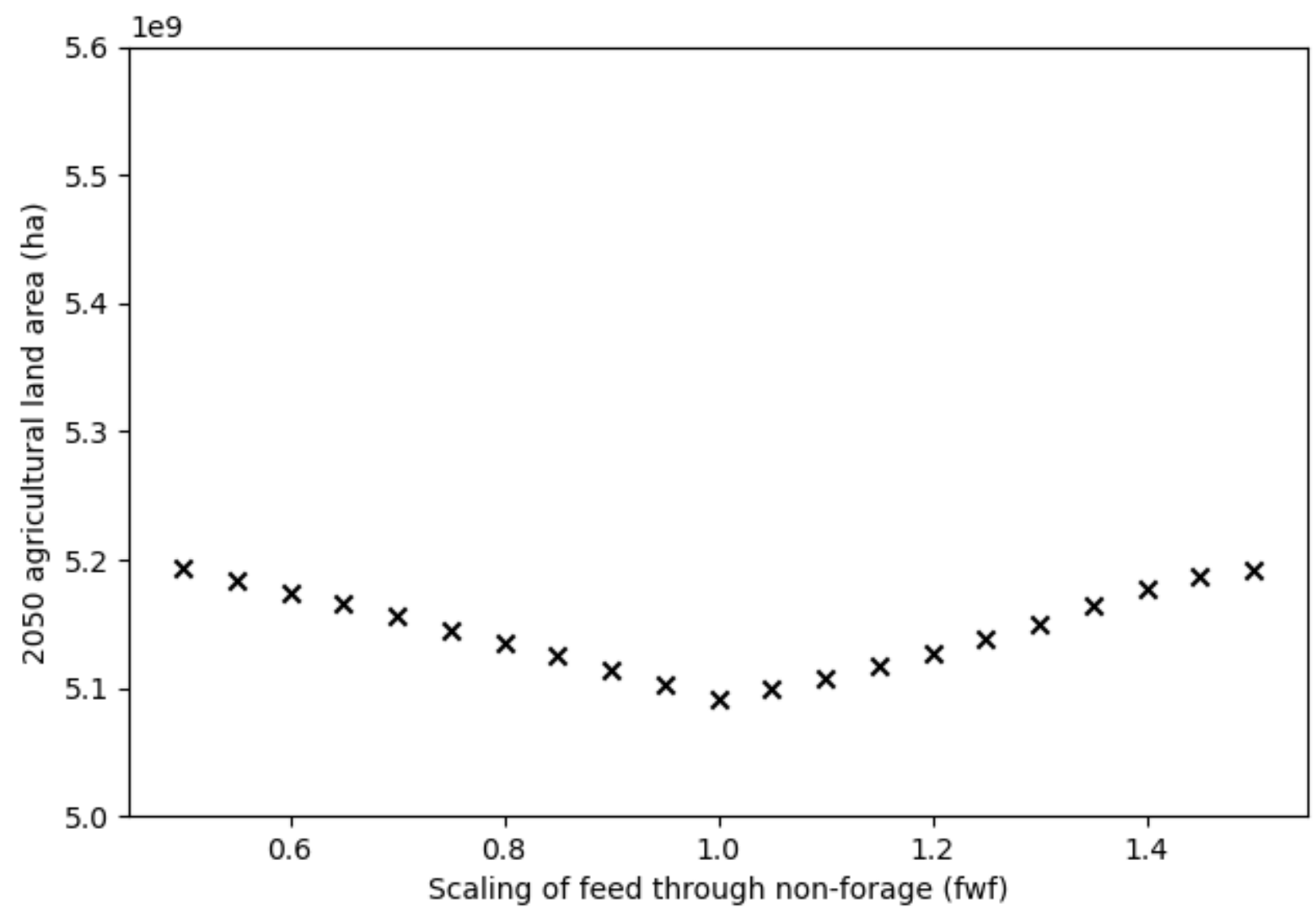

Figure C1. Change in global agricultural land-use when varying the proportion of livestock feed from non-forage (FWF).

Inspection of the land-use for pasture, fodder and food crops revealed that food crop land-use was constant as expected since only animal product production methods are being varied. Fodder crop land-use also behaved as expected - increasing with FWF, as more fodder crops must be produced to meet the feed demand of animals not produced on pasture. However, pasture did not behave as expected, instead following the same trend as the global land-use, with an increased land-use when varying the FWF factor in either direction. The cause of this behaviour has been identified as the scaling method applied to pasture 
land area. When the scaling is turned off, variations in the FWF factor lead to expected behaviour: global land use decreases

as FWF increases. The effective pasture yield is calculated using the projected 2017 land-use value before any scaling is applied. When FWF is increased the quantity of animal products produced on pasture decreases, including the 2017 value, however the historical pasture area remains unchanged. The result is an artificial decrease in effective pasture yield as FWF increases when the scaling is applied, as shown in Fig. C2.

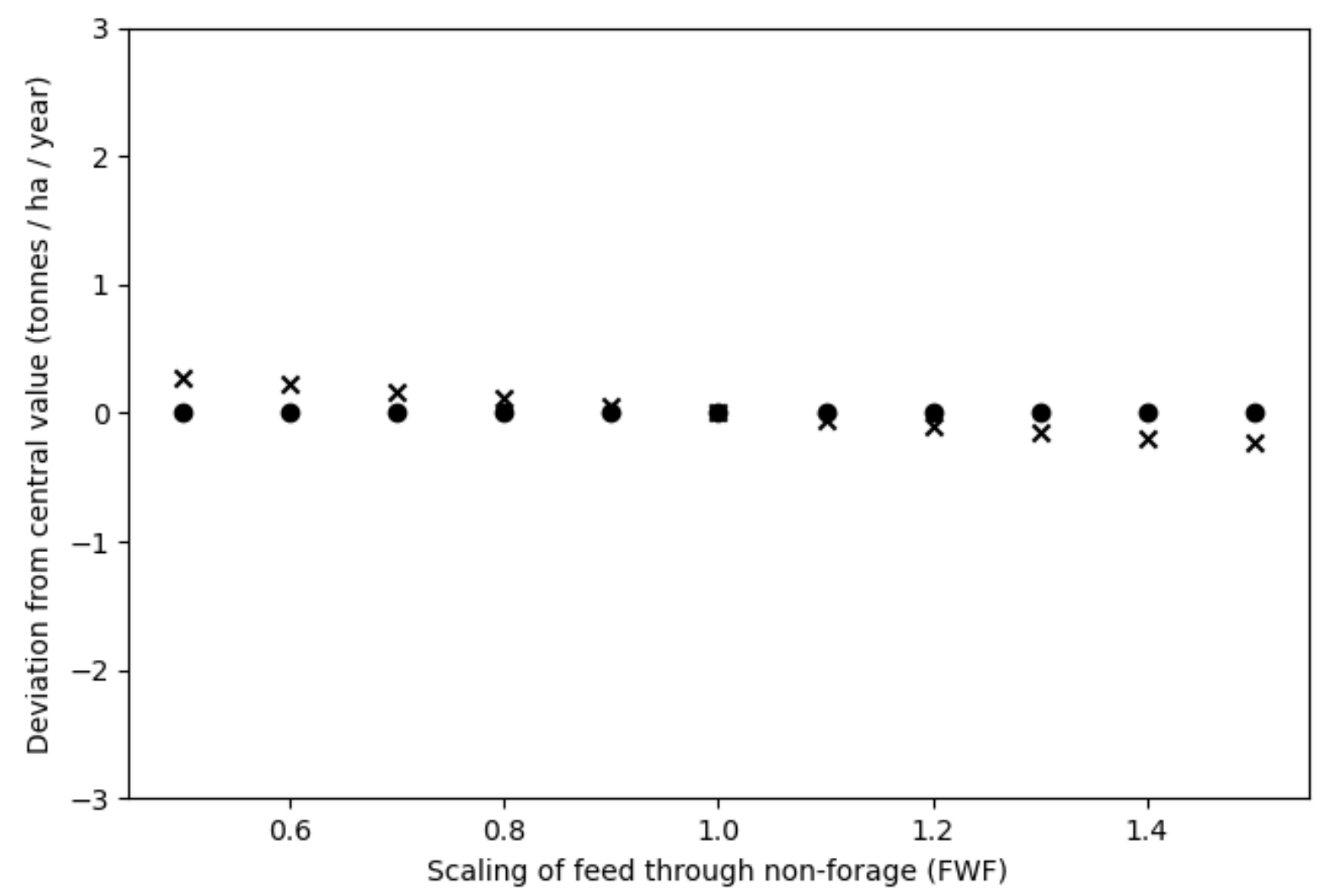

525 Figure C2. Magnitude of change in pre and post global mean scaled effective pasture yield for forced scaling of livestock feed through non forage (FWF).

To resolve this and any similar anomalies arising from scaling methods, the effective pasture yield is now scaled based on the projection pasture area in the anchor scenario, regardless of the scenario parameters. This can introduce minor discrepancies in the early years of the projection when setting factors to a fixed value, but this is not the normal mode of operation for the model. This sensitivity test varied the FWF factor for the entire projection, including the starting values, where in normal model operation any changes to this factor would be applied as a gradual deviation from the normal value. For example the scaling might vary from 1.0 in 2017 to 1.5 in 2050, as opposed to being 1.5 from the start as in this sensitivity analysis. 
https://doi.org/10.5194/gmd-2021-169

Preprint. Discussion started: 13 July 2021

(c) Author(s) 2021. CC BY 4.0 License.

(c) (i)

\section{Code availability}

C-LLAMA model source code can be found at 10.5281/zenodo.5083001.

\section{Author contributions}

TB developed C-LLAMA v1.0 and performed model runs. TB prepared the original manuscript, all co-authors contributed to manuscript review.

\section{Competing interests}

The authors declare that they have no conflict of interest.

\section{References}

Alexander, P., Brown, C., Arneth, A., Finnigan, J., and Rounsevell, M. D. A.: Human appropriation of land for food : The role of diet, Glob. Environ. Chang., 41, 88-98, https://doi.org/10.1016/j.gloenvcha.2016.09.005, 2016.

Alexander, P., Brown, C., Arneth, A., Finnigan, J., Moran, D., and Rounsevell, M. D. A.: Losses, inefficiencies and waste in the global food system, Agric. Syst., 153, 190-200, https://doi.org/10.1016/j.agsy.2017.01.014, 2017.

545 Allen, M. R., Dube, O. P., Solecki, W., Aragón-Durand, F., Cramer, W., Humphreys, S., Kainuma, M., Kala, J., Mahowald, N., Mulugetta, Y., Perez, R., Wairiu, M., and Zickfeld, K.: Framing and Context. Global Warming of $1.5^{\circ} \mathrm{C}$. An IPCC Special Report on the impacts of global warming of $1.5^{\circ} \mathrm{C}$ above pre-industrial levels and related global greenhouse gas emission pathways, in the context of strengthening the global response to the threat of climate change, sustainable development, and efforts to eradicate poverty. In Press. 2018.

550 Arneth, A., Denton, F., Agus, F., Elbehri, A., Erb, K., Osman Elasha, B., Rahimi, M., Rounsevell, M., Spence, M., Valentini, R.: Framing and Context. Climate Change and Land: an IPCC special report on climate change, desertification, land degradation, sustainable land management, food security, and greenhouse gas fluxes in terrestrial ecosystems. In press. 2019. Best, M. J., Pryor, M., Clark, D. B., Rooney, G. G., Essery, R. . L. H., Ménard, C. B., Edwards, J. M., Hendry, M. A., Porson, A., Gedney, N., Mercado, L. M., Sitch, S., Blyth, E., Boucher, O., Cox, P. M., Grimmond, C. S. B., and Harding, R. J.: The

555 Joint UK Land Environment Simulator (JULES), model description - Part 1: Energy and water fluxes, Geosci. Model Dev., 4, 677-699, https://doi.org/10.5194/gmd-4-677-2011, 2011.

Bijl, D. L., Bogaart, P. W., Dekker, S. C., Stehfest, E., de Vries, B. J. M., and van Vuuren, D. P.: A physically-based model of long-term food demand, Glob. Environ. Chang., 45, 47-62, https://doi.org/10.1016/j.gloenvcha.2017.04.003, 2017.

Calvin, K., Wise, M., Clarke, L., Edmonds, J., Kyle, P., Luckow, P., and Thomson, A.: Implications of simultaneously mitigating and adapting to climate change: Initial experiments using GCAM, Clim. Change, 117, 545-560, 
https://doi.org/10.5194/gmd-2021-169

Preprint. Discussion started: 13 July 2021

(c) Author(s) 2021. CC BY 4.0 License.

https://doi.org/10.1007/s10584-012-0650-y, 2013.

Davis, K. F. and D'Odorico, P.: Livestock intensification and the influence of dietary change: A calorie-based assessment of competition for crop production, Sci. Total Environ., 538, 817-823, https://doi.org/10.1016/j.scitotenv.2015.08.126, 2015. Van Dyk, J. S., Gama, R., Morrison, D., Swart, S., and Pletschke, B. I.: Food processing waste: Problems, current management and prospects for utilisation of the lignocellulose component through enzyme synergistic degradation, Renew. Sustain. Energy Rev., 26, 521-531, https://doi.org/10.1016/j.rser.2013.06.016, 2013.

Fricko, O., Havlik, P., Rogelj, J., Klimont, Z., Gusti, M., Johnson, N., Kolp, P., Strubegger, M., Valin, H., Amann, M., Ermolieva, T., Forsell, N., Herrero, M., Heyes, C., Kindermann, G., Krey, V., McCollum, D. L., Obersteiner, M., Pachauri, S., Rao, S., Schmid, E., Schoepp, W., Riahi, K.: The marker quantification of the Shared Socioeconomic Pathway 2: A middleof-the-road scenario for the 21st century, Global Environ. Change, 42, 251-267, 10.1016/j.gloenvcha.2016.06.004, 2017.

Frieler, K., Schauberger, B., Arneth, A., Balkovič, J., Chryssanthacopoulos, J., Deryng, D., Elliott, J., Folberth, C., Khabarov, N., Müller, C., Olin, S., Pugh, T. A. M., Schaphoff, S., Schewe, J., Schmid, E., Warszawski, L., and Levermann, A.: Understanding the weather signal in national crop-yield variability, Earth's Futur., 5, 605-616, https://doi.org/10.1002/2016EF000525, 2017.

575 Fujimori, S., Masui, T., and Matsuoka, Y.: AIM/CGE [basic] manual, Discuss. Pap. Ser., 74, 2012.

Gustavsson, J. and Cederberg, C.: Global Food losses and Food waste, 1, 2011.

Haberl, H., Erb, K. H., Krausmann, F., Gaube, V., Bondeau, A., Plutzar, C., Gingrich, S., Lucht, W., and Fischer-Kowalski, M.: Quantifying and mapping the human appropriation of net primary production in earth's terrestrial ecosystems, Proc. Natl. Acad. Sci. U. S. A., 104, 12942-12947, https://doi.org/10.1073/pnas.0704243104, 2007.

580 Havlík, P., Valin, H., Herrero, M., Obersteiner, M., Schmid, E., Rufino, M. C., Mosnier, A., Thornton, P. K., Böttcher, H., Conant, R. T., Frank, S., Fritz, S., Fuss, S., Kraxner, F., and Notenbaert, A.: Climate change mitigation through livestock system transitions, Proc. Natl. Acad. Sci. U. S. A., 111, 3709-3714, https://doi.org/10.1073/pnas.1308044111, 2014.

Holman, B. W. B. and Malau-Aduli, A. E. O.: Spirulina as a livestock supplement and animal feed, J. Anim. Physiol. Anim. Nutr. (Berl)., 97, 615-623, https://doi.org/10.1111/j.1439-0396.2012.01328.x, 2013.

585 Iizumi, T., Furuya, J., Shen, Z., Kim, W., Okada, M., Fujimori, S., Hasegawa, T., and Nishimori, M.: Responses of crop yield growth to global temperature and socioeconomic changes, Sci. Rep., 7, 1-10, https://doi.org/10.1038/s41598-017-08214-4, 2017.

KC, S. and Lutz, W.: The human core of the shared socioeconomic pathways: Population scenarios by age, sex and level of education for all countries to 2100, Glob. Environ. Chang., 42, 181-192, https://doi.org/10.1016/j.gloenvcha.2014.06.004, 2017.

Kearney, J.: Food consumption trends and drivers, 2793-2807, https://doi.org/10.1098/rstb.2010.0149, 2010.

Kitinoja, L.: Use of cold chains for reducing food losses in developing countries, PEF White Pap., 6, 1-16, 2013.

Kottek, M., Grieser, J., Beck, C., Rudolf, B., and Rubel, F.: World Map of the Köppen-Geiger climate classification updated. Meteorol. Z., 15, 259-263. DOI: 10.1127/0941-2948/2006/0130, 2006. 
https://doi.org/10.5194/gmd-2021-169

Preprint. Discussion started: 13 July 2021

(c) Author(s) 2021. CC BY 4.0 License.

Krausmann, F., Erb, K. H., Gingrich, S., Lauk, C., and Haberl, H.: Global patterns of socioeconomic biomass flows in the year 2000: A comprehensive assessment of supply, consumption and constraints, Ecol. Econ., 65, 471-487, https://doi.org/10.1016/j.ecolecon.2007.07.012, 2008.

Lambin, E. F. and Meyfroidt, P.: Global land use change , economic globalization , and the looming land scarcity, 108, https://doi.org/10.1073/pnas.1100480108, 2011.

600 Lambin, E. F., Geist, H. J., and Lepers, E.: Dynamics of land-use and land-cover change in tropical regions, Annu. Rev. Environ. Resour., 28, 205-241, https://doi.org/10.1146/annurev.energy.28.050302.105459, 2003.

Lipinski, B., Hanson, C., Lomax, J., Kitinoja, L., Waite, R., and Searchinger, T.: Reducing Food Loss and Waste, 1-40, 2013. Liu, C., Hotta, Y., Santo, A., Hengesbaugh, M., Watabe, A., Totoki, Y., Allen, D., and Bengtsson, M.: Food waste in Japan: Trends, current practices and key challenges, J. Clean. Prod., 133, 557-564, https://doi.org/10.1016/j.jclepro.2016.06.026, 6052016.

Mueller, N. D., Gerber, J. S., Johnston, M., Ray, D. K., Ramankutty, N., and Foley, J. A.: Closing yield gaps through nutrient and water management, Nature, 490, 254-257, https://doi.org/10.1038/nature11420, 2012.

Oerke, E. C. and Dehne, H. W.: Safeguarding production - Losses in major crops and the role of crop protection, Crop Prot., 23, 275-285, https://doi.org/10.1016/j.cropro.2003.10.001, 2004.

610 Oliveira Vieira, E., Venturoso, O. J., Reinicke, F., Cézar, C., Silva, D., Oliveira Porto, M., Cavali, J., Vieira, N. T., and Ferreira, E.: Production, Conservation and Health Assessment of Acid Silage Vicera of Freshwater Fish as a Component of Animal Feed, Int. J. Agric. For., 5, 177-181, https://doi.org/10.5923/j.ijaf.20150503.01, 2015.

Parfitt, J., Barthel, M., and MacNaughton, S.: Food waste within food supply chains: Quantification and potential for change to 2050, Philos. Trans. R. Soc. B Biol. Sci., 365, 3065-3081, https://doi.org/10.1098/rstb.2010.0126, 2010.

615 Pikaar, I., Matassa, S., Bodirsky, B. L., Weindl, I., Der, F. H., Rabaey, K., Boon, N., Bruschi, M., Yuan, Z., Zanten, H. Van, Herrero, M., Verstraete, W., and Popp, A.: Decoupling Livestock from Land Use through Industrial Feed Production Pathways, https://doi.org/10.1021/acs.est.8b00216, 2018.

Popp, A., Rose, S. K., Calvin, K., Vuuren, D. P. Van, Dietrich, J. P., Wise, M., Stehfest, E., Humpenöder, F., Kyle, P., Vliet, J. Van, Bauer, N., Lotze-campen, H., Klein, D., and Kriegler, E.: Land-use transition for bioenergy and climate stabilization :

620 model comparison of drivers, impacts and interactions with other land use based mitigation options, 495-509, https://doi.org/10.1007/s10584-013-0926-x, 2014.

Powell, T.: Closing loops to rebalance the global carbon cycle: Biomass flows modelling of global agricultural carbon fluxes, PhD Thesis Univ. Exet., 2015.

Powell, T. W. R. and Lenton, T. M.: Future carbon dioxide removal via biomass energy constrained by agricultural efficiency 625 and dietary trends, https://doi.org/10.1039/c2ee21592f, 2012.

Ray, D. K., Ramankutty, N., Mueller, N. D., West, P. C., and Foley, J. A.: Recent patterns of crop yield growth and stagnation, Nat. Commun., 3, 1293-1297, https://doi.org/10.1038/ncomms2296, 2012.

Ray, D. K., Gerber, J. S., Macdonald, G. K., and West, P. C.: Climate variation explains a third of global crop yield variability, 
https://doi.org/10.5194/gmd-2021-169

Preprint. Discussion started: 13 July 2021

(c) Author(s) 2021. CC BY 4.0 License.

(c) (i)

Nat. Commun., 6, 1-9, https://doi.org/10.1038/ncomms6989, 2015.

630 Rolinski, S., Müller, C., Heinke, J., Weindl, I., Biewald, A., Leon Bodirsky, B., Bondeau, A., Boons-Prins, E. R., Bouwman, A. F., Leffelaar, P. A., Roller, J. A. T., Schaphoff, S., and Thonicke, K.: Modeling vegetation and carbon dynamics of managed grasslands at the global scale with LPJmL 3.6, Geosci. Model Dev., 11, 429-451, https://doi.org/10.5194/gmd-11-429-2018, 2018.

Van Rossum, G. and Drake Jr, F. L.: Python reference manual, Centrum voor Wiskunde en Informatica Amsterdam, 1995.

635 Savary, S., Ficke, A., Aubertot, J. N., and Hollier, C.: Crop losses due to diseases and their implications for global food production losses and food security, Food Secur., 4, 519-537, https://doi.org/10.1007/s12571-012-0200-5, 2012.

Shepon, A., Eshel, G., Noor, E., and Milo, R.: Energy and protein feed-to-food conversion efficiencies in the US and potential food security gains from dietary changes Energy and protein feed-to-food conversion ef fi ciencies in the US and potential food security gains from dietary changes, 2016.

640 Singh, I. D. and Stoskopf, N. C.: Harvest Index in Cereals1, Agron. J., 63, 224-226, https://doi.org/https://doi.org/10.2134/agronj1971.00021962006300020008x, 1971.

Stancu, V., Haugaard, P., and Lähteenmäki, L.: Determinants of consumer food waste behaviour: Two routes to food waste, Appetite, 96, 7-17, https://doi.org/10.1016/j.appet.2015.08.025, 2016.

Thornton, P. K.: Livestock production: Recent trends, future prospects, Philos. Trans. R. Soc. B Biol. Sci., 365, 2853-2867,

645 https://doi.org/10.1098/rstb.2010.0134, 2010.

Tilman, D. and Clark, M.: Global diets link environmental sustainability and human health, Nature, 515, 518-522, https://doi.org/10.1038/nature13959, 2014.

Tsugane, S. and Sawada, N.: The JPHC study: Design and some findings on the typical Japanese diet, Jpn. J. Clin. Oncol., 44, 777-782, https://doi.org/10.1093/jjco/hyu096, 2014.

650 Tufarelli, V., Ragni, M., and Laudadio, V.: Feeding forage in poultry: A promising alternative for the future of production systems, Agric., 8, 1-10, https://doi.org/10.3390/agriculture8060081, 2018.

Vuuren, D. P. Van, Edmonds, J., Kainuma, M., Riahi, K., Nakicenovic, N., Smith, S. J., and Rose, S. K.: The representative concentration pathways : an overview, 5-31, https://doi.org/10.1007/s10584-011-0148-z, 2011.

Wirsenius, S., Azar, C., and Berndes, G.: How much land is needed for global food production under scenarios of dietary

655 changes and livestock productivity increases in 2030 ?, Agric. Syst., 103, 621-638, https://doi.org/10.1016/j.agsy.2010.07.005, 2010.

World Bank. Worldwide Governance Indicators (WGI) Project. The World Bank, Washington DC, USA, 2020.

Van Zanten, H. H. E., Herrero, M., Van Hal, O., Röös, E., Muller, A., Garnett, T., Gerber, P. J., Schader, C., and De Boer, I. J. M.: Defining a land boundary for sustainable livestock consumption, Glob. Chang. Biol., 24, 4185-4194, 660 https://doi.org/10.1111/gcb.14321, 2018. 